\title{
Müftîzâde Muhammed b. Hamza'nın Taklit ve İkrah Altında Gerçekleşen Talâka Dair Risâlesinin Tahkik, Tahlil ve Tercümesi
}

\author{
The Critical Edition, Analysis and Translation of Muftīzāde \\ Muhammad b. Hamza's Treatise on Divorce Performed under Duress \\ and Taqlid
}

\section{Mehmet Yuşa SOLAK*}

Öz: Bu makale Osmanlı âlimlerinden Müftîzâde Muhammed b. Hamza’ya ait bir risâlenin tahkik, tahlil ve tercümesini konu edinmektedir. Müellif Müftîzâde bu eserinde "fetva", "taklit" ve "ikrah altında gerçekleşen talâk"la ilgili konuları incelemektedir. $\mathrm{Mu}$ hammed b. Hamza, içinde bulunduğu dönemin şartlarını göz önüne alarak ikrah altında gerçekleşen talâkın geçersiz sayılması gerektiğini savunmaktadır. Bu görüşüyle yaşadığı coğrafyada hakim konumda bulunan Hanefî mezhebinin görüşlerinin dışına çıkan müellif, bu tutumunu sağlam bir zemine oturtmak için risâlenin giriş kısmında taklidle ilgili hükümleri incelemiştir. Gerektiği takdirde farklı müctehidlerin görüşlerinin aynı zaman diliminde uygulanabileceği konusunu sağlam bir zemine oturtan müellif, ikrah altında gerçekleşen talâk hususunda da Mâlikî, Şâfiî ve Hanbelî mezheplerine ait görüşün uygulanmasını yaşadığı dönemin şartlarına uygun bulmaktadır. Makalede konu iki bölüm halinde incelenmektedir. Birinci bölüm müellif ve risâle hakkında genel bir bilgi içermekte, çalışmanın ikinci ve esas bölümünü ise risâlenin tahkik ve tercümesi oluşturmaktadır.

Anahtar kelimeler: Fetva, Taklit, Müftü

Abstract: The aim of this article is to evaluate the critical edition, analysis and translation of a treatise that was written by the Ottoman scholar Muftizāde Muhammad b. Hamza. In his treatise, the author investigated the issues of fatwa and taqli $d$ related to divorce performed under duress ( $i k r a \bar{h})$. Considering the conditions of his time, Muhammad b. Hamza maintains the necessity of nullifying the divorce performed under duress. With this opinion, the author parts from the views of the Hanafi school, which had the prevailing position in the region where he lived. Furthermore, in order to strengthen his position, Muftizāde Muhammad b. Hamza investigates the provisions related with imitation (taqlid) in the introduction of the treatise. Building on the issue that the views of different mujtahids can be performed simultaneously if required on solid ground; the author deems the view of the Mālikī, the Shäfíi and the Hanbalì schools suitable on divorce performed under duress for the conditions of his time. The present article examines the subject in two sections. The first section contains general knowledge on the author and his treatise, which is followed by the bulk of the study that entails the critical edition and analysis of the treatise.

Keywords: Fatwā, Taqlīd, Muftī

* Arş. Gör. Marmara Üniversitesi İlahiyat Fakültesi İslâm Hukuku Anabilim Dalı,E-posta: mehmetyusasolak@hotmail.com 


\section{Müellif ve Risâle Hakkında Kısa Bir Giriș}

Risâlenin müellifi olan âlim Muhammed b. Hamza, isminden ziyade "Müftîzâde", "Hacı Emîrzâde", "Güzelhisârî”, "Âlim Mehmet Efendi” gibi lakaplarıyla tanınan bir Osmanlı âlimidir. Tarihçiler tarafından "allâme”, "üstad", "mütefennin", "fıkıh ilminde mâhir” gibi vasıflarla anılan müellifin hayatı hakkında yeterli bilgi bulunmamaktadır. Doğum yeriyle ilgili kaynaklarda herhangi bir bilgiye rastlayamadığımız Muhammed b. Hamzảnın Aydın'da yaşadığı ve buraya defnedildiği kaydedilmektedir. Vefat tarihi olarak 1110/1698, 1116/1704, 1204/1790, 1121/1709 yılları zikredilmekle birlikte, risâlelerine düştüğü ferağ kayıtlarından müellifin 1118/1706 yılından sonra vefat ettiği anlaşılmaktadır. Bu kayıtlar, müellifin 1121/1709 tarihinde vefat etmiş olma ihtimalini kuvvetlendirmektedir. ${ }^{1}$ Muhammed b. Hamza’nın yetişmesi ve ilim tahsili süreciyle ilgili yeterli malumat mevcut değilse de Anadolu'dan çıktı̆̆ını gösteren bir kaydın bulunmayışı, eğitimini Osmanlı âlimleri elinde tamamladığını düşündürmektedir. Öte yandan bazı araştırmacılar müellifin babasını hocaları arasında zikreder. ${ }^{2}$ Müellife ait olan Ezhâru't-tenzîl adlı tefsirin bir nüshasında müstensihin Müftîzâde'den "babam” diye bahsetmesi, oğlunun da yetiştirdiği öğrenciler arasında olduğunu gösterir. ${ }^{3} \mathrm{Mu}$ hammed b. Hamza'nın telif ettiği eserlerin neredeyse tamamı risâle tarzında olup bunların 60’1 fıkıh ilmiyle ilgilidir. ${ }^{4}$ Bu durum, müellifin müftülük vazifesinden dolayı sürekli fıkhî sorulara muhatap olmasından kaynaklanmış olmalıdır.

Muhammed b. Hamza’nın makalemize konu olan risâlesinin Türkiye kütüphanelerinde ve yurt dışında çeşitli nüshaları bulunmaktadır. Eserin yedi farklı nüshası ${ }^{5}$ tarafımızca temin edilerek incelenmişse de bunlardan dördü tahkikte esas alınmış, Çelebi Abdullah Kütüphanesi’nde yer alan nüsha, ana nüsha kabul edilmiştir. ${ }^{6}$ Müellifi tarafından özel olarak

1 Bağdatlı İsmail Paşa, Hediyyetü'l-ârifîn esmâül-müellifîn ve âsâru'l-musannifîn, I-II, Beyrut: Dâru ihyâi't-türâsi'lArabî, 1951, II, 246; a.mlf., Îzâhu'l-meknûn, I-IV, Beyrut: Dâru ihyâi't-türâsi'l-Arabî, ts., V, 216; Bursalı Mehmet Tahir, Osmanlı Müellifleri (haz. A. Fikri Yavuz-İsmail Özen), I-III, İstanbul: Meral Yayınları, ts., I, 294; Ömer Nasûhî Bilmen, Büyük Tefsir Tarihi, İstanbul: Bilmen Yayınları, 1971, II, 732; Recep Cici, Bir Osmanlı Fakihi Âlim Muhammed b. Hamza'nın Fıkıh Risâleleri, Bursa: Emin Yayınları, ts., s. 17.

2 Cici, Bir Osmanlı Fakihi, s. 17; Seyda Demirci, Hacı Emirzâde Muhammed b. Hamza el-Aydınînin Hayatı, Eserleri ve Günlük Hayata Dair Bazı Risâlelerinin Tanıtımı (yüksek lisans tezi, 2014), Marmara Üniversitesi Sosyal Bilimler Enstitüsü, s. 16-7.

3 Muhammed b. Hamza el-Aydînî, Ezhâru't-tenzîl fî esrâri't-te’vîl, Hacı Mahmud Efendi Ktp. nr. 140.

4 Cici, Bir Osmanl Fakihi, s. 23.

5 Risâleye ait yukarıda zikredilen Çelebi Abdullah (nr. 388/14, 229a-232a) nüshasından başka Esad Efendi (nr. 3699/43, 117 ${ }^{\mathrm{a}}-119^{\mathrm{b}}$ ); Süleymaniye (nr. 1038/20, 25 $5^{\mathrm{b}}-27^{\mathrm{b}}$ ); Râşit Efendi (nr. 1178/13, 31 ${ }^{\mathrm{b}}-33^{\mathrm{b}}$ ); Âtıf Efendi, (nr.

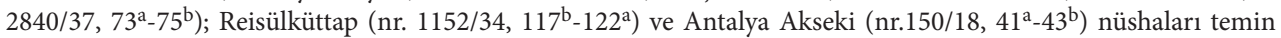
edilerek incelenmiştir. Tahkikte esas alınan nüshaların rumuzları şu şekildedir: Çelebi Abdullah:ج , Esad Efendi: أ , Süleymaniye:w, Raşit Efendi: J.

6 Tahkik esnasında Türkiye Diyanet Vakfı İslâm Araştırmaları Merkezi (İSAM) tahkik kuralları ölçü alınmak suretiyle nüshalar arasında - ana nüshadan farklı da olsa - metni en doğru şekilde yansıtan ibare esas alınmıştır. Diğer nüshalardaki farklılıklara ise dipnotta işaret edilmiştir (Metin üzerinde noktalama işaretlerinin kullanımı hususunda makalenin neşredildiği derginin gerekli gördüğü müdahaleler yapılmıştır). İSAM tahkik esasları için bk.http://www.isam.org.tr/documents/_dosyalar/_pdfler/Arapca_Tahkik_Dizgi_Bibliyografya_Esaslari.pdf (erişim tarihi: 27.11.2017). 
isimlendirilmediği anlaşılan risâle, kütüphane kataloglarında farklı adlarla kaydedilmektedir. ${ }^{7}$ Müellifin taklit ve talâk meseleleri arasında kurduğu ilişki, eserin asıl yazılış amacının "mükrehin talâkı" olduğunu ortaya koymaktadır. Bu nedenle içeriğine ve ana konusuna uygun olması için risâle hakkında "Risâle fî ahkâmi't-taklîd ve talâki'l-mükreh/Taklidin Hükümlerine ve Mükrehin Talâkına Dair Bir Risâle” ismini kullanmayı uygun gördük.

Muhammed b. Hamza, risâlesinde ilk olarak taklidin meşruiyeti ve nasıl olması gerektiği konularını ele almış, sonrasında ikrah altında gerçekleşen talâkın hükmü hakkında fakihlerin görüş ve delillerini zikretmiştir. Mükrehin talâkını geçersiz sayan fakih ve mezheplerin delillerini itimada şayan bulan müellif, bu konuda Şâfiî mezhebinin görüşünün yaşadığı dönemin şartlarına daha uygun olduğunu ifade etmektedir.

Muhammed b. Hamza, ictihad melekesine sahip olmayan kişilerin görevinin müftünün fetvâsına uymak olduğunu belirtir. Ona göre, fetvâ soran kimse belirli bir müftüye bağlllık göstermek zorunda olmayıp değişik meseleler karşısında farklı müftülerden fetvâ isteyebilir. Müftîzâde bu yaklaşımı bütünüyle Hanefî fakihlerin ifadelerini referans göstererek temellendirir. Kısa sayılabilecek bir risâlede giriş bölümünü oluşturan taklit konusunun etraflıca incelenmesi, müellifin metin tasarımında başarısız olduğunu düşündürebilir. Öyle ki; bu durum kimilerinin eserin ana konusu olarak taklidi görmelerine ve risâleye bu doğrultuda isimler vermelerine neden olmuştur. Bize göre Muhammed b. Hamza böyle yapmakla, yaşadığı dönem ve coğrafyada hâkim konumda bulunan Hanefîlerden gelecek eleştirilerin önünü kesmek istemiş olmalıdır. Bu konuda tamamen Hanefî kaynaklara atıflar yapıyor olması da bu tespiti desteklemektedir. Müellifin bu amaç doğrultusunda hareket ettiğini teyit eden bir diğer husus, Ebû Cáfer et-Tahâvî (ö. 321/933) ve Kerhî (ö. 340/952) gibi ikrah altında gerçekleşen talâkın - kasıt bulunmadığı takdirde - geçersiz olacağını savunan Hanefî fakihlerden ${ }^{8}$ hiç bahsetmiyor oluşudur. Çünkü o, pek çok Hanefî fakihten zaruret halinde diğer müctehidlerin görüşleriyle amel etmenin cevazını nakletmekle, kendisine daha geniş bir referans ağı teşkil etmiş bulunuyordu.

Fikıh usûlünde taklidin meşruiyeti ve gerekliliği ele alınırken insanlar âlim-âmmî ayrımına tabi tutulurlar. ${ }^{9}$ "Eğer bilmiyorsanız zikir erbabına sorun" 10 âyeti, bu ayrımın temel

7 Bunlar arasında Risâle fi't-taklîdi bi'l-müctehidîn, Risâle fi't-taklîd, er-Risâletü't-taklîdiyye, Risâle fi talâki'l-mükreh gibi isimler yer alır. Makale yayın aşamasındayken tahkik ve tercümesini konu edindiği risâle Abdüsselam Arı tarafından yalnızca tahkik ve tahlilli metin olarak et-Taklîd ve talâku'l-mükreh adıyla yayınlanmıştır ("et-Taklîd ve talâku'l-mükreh", İslâm Hukuku Araştırmaları Dergisi, 2016, sy. 27, s. 713-741).

8 Zeynüddîn b. İbrahim el-Mısrî İbn Nüceym, el-Bahru'r-râik şerhu Kenzid-dekâik. I-VIII, Beyrut: Dâru'l-kitâbi'lİslâmî, ts., III, 266. Hanefî mezhebinin temel metinlerinden biri olan Ahmed b. Ebû Bekir el-Kudûrîye (ö. 438/1037) ait el-Muhtasar'ın bazı nüshalarında "Sarhoşken yahut ikrah altında hanımını boşayan kişi bu hal zail olduktan sonra hanımını kasıtlı olarak boşadığını söyleyecek olsa bu sözü dikkate alınarak hanımı ondan boşanmış sayılır" ifadelerine yer verilmektedir. el-Muhtasar'nn önemli şârihlerinden Ebû Bekir b. Ali el-Haddâd (ö. 800/1398) bu ifadeden yola çıarak Kudûrî nezdinde de Tahâvî ve Kerhînin delillerinin kuvvetli olduğunu ifade etmektedir (Ebû Bekir b. Ali el-Haddâd, el-Cevheretün-neyyira, I-II, yy.: el-Matbaatü'l-hayriyye, ts., II, 39).

9 Eyüp Said Kaya, “Taklid”, DİA, XXXIX, 461.

10 16/en-Nahl: 43. 
dayanakları arasında yer alır. ${ }^{11}$ İslâm hukukçuları, âyette soru sorulan kesimi oluşturan müctehidlerin şahsi görüş ve ictihadlarına uygun amel etmeleri gerektiğini söylerler. Fetvâ soran mukallidin ise mutlak surette bir müctehidi taklit etmesi gerektiğini söyleyen fakihler olduğu ${ }^{12}$ gibi amele esas teşkil eden bilgiyi dikkate alarak ayrım yapanlar da bulunmaktadır. $\mathrm{Bu}$ ikinci grubu oluşturan hukukçulara göre müctehid olsun olmasın herkesin vâkıf olduğu namaz, oruç, zekât ve haccın farz; zina etme, içki içme ve adam öldürmenin haram olması gibi hükümlerde bir müctehidi taklide gerek yoktur. Fakat akıl yürütmeye ve muhakemeye ihtiyaç duyan konularda mukallid müctehidi taklit etmelidir. ${ }^{13}$

Taklit ehlinden olan bir kimsenin tüm meselelerde belirli bir müctehide uyması - çoğunluğa göre - bir zorunluluk kabul edilmemiştir. Muhammed b. Hamzảnın bu doğrultuda Zâhidî (ö. 658/1260) ve İbnü’l-Hümâm (ö. 861/1457) gibi Hanefî fakihlerden yaptığı nakiller kendisinin de bu görüsse katıldığını gösteriyor. İbn Emîru Hâc (ö. 879/1474), Allah ve Resûlü’nden sadır olan bir emir bulunmadıkça tüm meselelerde belirli bir müctehide uyma zorunluluğundan bahsedilemeyeceğini ifade eder. ${ }^{14}$ Öte yandan belirli bir konuda bir müctehid taklit edildiğinde aynı konuda farklı bir müctehidin taklit edilmesi caiz görülmemiştir. Zira mukallid bu konuda müctehid gibi kabul edilmektedir. Bu kabule göre, müctehid, bir konuda iki delilden biriyle amel ettiği takdirde kalbinde diğer delilin daha güçlü olduğuna dair kanaat oluşmadıkça amel ettiği görüşünden dönemediği gibi mukallid de amel ettiği bir mezhebi bırakıp "aynı konuda" başka bir mezhebi taklit edemez. ${ }^{15}$

İslâm hukukçuları farklı mezheplerin görüşleriyle fetvâ vermenin cevâzı noktasında hemfikir oldukları için Hanefî olan İbnü’l-Hümâm ve öğrencisi İbn Emîru Hâc, farklı mezhepten bir görüşle fetvâ vermenin cevâzını ispat sadedinde Mâlikî ve Şâfiî hukukçuların sözlerini delil olarak zikretmişlerdir. ${ }^{16}$ İlk bakışta pek makul görünmeyen bu duruma taklit konusunda da eser telif eden ${ }^{17}$ Hanefî fakihi Muhammed b. Abdülmelik el-Bağdâdî (ö. 1016/1607) şöyle cevap verir: "Bir mesele imamların tamamının kabulüne şayan olursa onlardan her birinin sözünü delil getirmek caiz olur. Farklı mezhepten olan müctehidi taklit etmek ve onun görüşüyle fetvâ vermek de bu kabildendir." 18

Muhammed b. Hamza yaptığı nakiller üzerinden taklit konusunu vuzuha kavuşturduktan sonra ikrah altında gerçekleşen talâk meselesini incelemeye başlar. Birtakım eşkıyaların

11 Muhammed Emîn b. Mahmud el-Buhârî el-Mekkî Emîr Pâdişâh, Teysîru’t-Tahrîr (nşr. Mustafa el-Bâbî el-Halebî), I-IV, Beyrut: Dâru'l-kütübi'l-ilmiyye, 1351/1932, IV, 246. Karaman), İctihad, Taklid ve Telfik Üzerine Dört Risale, İstanbul: İz Yayıncılık, 2000, s. 77-8.

Ebû Abdullah Şemsüddîn Muhammed b. Muhammed el-Halebî İbn Emîr Hâc, et-Takrîr ve't-tahbîr, I-III, Beyrut: Dâru'l-kütübi'l-ilmiyye, 1403/1983, III, 353.

Nablusî, Hülâsa, s. 5. 
insanların mallarını cebren alabilmek için talâk üzerine yemin ettirdiğini belirten müellif, bu durumun insanların ailevî ve malî ilişkilerinin selâmetini tehdit ettiğinin farkındadır ve problemin çözümü için uygulamada Şâfiî mezhebinin görüşünü esas almayı önerir.

Mükrehin talâkı hakkında İslâm hukukçuları arasında yaşanan görüş ayrılıkları, fikıh usulünde incelenen "ehliyet arızaları" bahsi ile doğrudan alakalıdır. "Müktesep ehliyet arızaları" arasında sayılan ikrah, Hanefîlere göre bir tasarrufu batıl kılmaz. İkrahın etkisi yalnızca mükrehin fiilinin kime nispet edileceğini belirleme noktasında kendini gösterir. Zorlayıcıya (mükrih) nispet edilmesi mümkün olan "mala yönelik itlâf" gibi fiilî tasarruflarda zorlanan kişi (mükreh) bir alet/vasıta kabul edilir ve sorumluluğun mükrihe ait olduğu söylenir. Bu nispetin mümkün olmadığı kavlî tasarruflar ise feshedilebilir nitelikte olması durumunda fâsid kabul edilirken feshi kabil olmadığı takdirde mükreh adına gerçekleşmiş sayılır. Çünkü ikrah rızayı yok ediyor olsa da ihtiyarı ortadan kaldırmaz. Mükrehin talâkı ikinci kısma giren feshi kabil fiillerden olduğu için muteber sayılmıştır. ${ }^{19}$ Hanefîler bu konuda Hz. Peygamber'in hâzilin (şaka niyetiyle işlem yapan) talâkını geçerli saymasını ${ }^{20}$ delil olarak zikrederler. Bu rivayet Şâriin irade edilmeyen "talâk" lafzını hukuken muteber kabul ettiğini gösterir. İkrah altında vukû bulan boşamada "talâk" lafzına irade de eşlik ettiği için bu işlem geçerlilik kazanmayı evleviyetle hak etmektedir. ${ }^{21}$ Şâfiî mezhebinde ise işlenmesi ikrah sebebiyle caiz hale gelen fiiller mükrihe nispet edilemediği takdirde batıl kabul edilip üzerlerine bir hüküm terettüp etmez. Bu nedenle de mükrehin talâkı geçersiz kabul edilmektedir. ${ }^{22}$

İslâm hukukunda ta'lîk (şarta bağlama) yoluyla yapılan boşamalar yemin (yemîn bi'ttalâk) olarak da ifade edilir. Bunun nedeni hem yemin hem de şarta bağlı yapılan boşamalarda kişiyi kerih gördüğü bir davranıştan alıkoyma ve arzu ettiği bir fiili eda etme konusunda teşvik etme özelliğinin bulunuyor oluşudur. ${ }^{23}$ İslâm hukukçularının çoğunluğuna göre şarta bağlı boşamalarda şartın tahakkuk etmesi durumunda talâk gerçekleşmektedir. ${ }^{24}$ $\mathrm{Bu}$ işlemin yemin olarak isimlendirilmesi mecâzî olup bu isimlendirme talâkın dışında yemini ilgilendiren birtakım sonuçların doğmasına neden olmaz. ${ }^{25}$ Hanbelî fakihlerden İbn

19 Sa‘düddîn Mesîud b. Fahruddîn Ömer Abdullah et-Teftâzânî, Şerhü’t-Telvîh ale’t-Tavdîh, I-II, yy., ts., II, 392; Muhammed b. Ferâmuz b. Ali Molla Hüsrev, Mirkâtü'l-vusûl ilâ ilmi'l-usûl (nşr. İlyas Kaplan), Beyrut: Dâru'lkütübi'l-ilmiyye, 1433/2012, s. 357, 359.

20 Ebû Abdullah Muhammed b. Yezîd İbn Mâce el-Kazvînî, es-Sünen (nşr. Şuayb el-Arnaût - Âdil Mürşid), I-V, Beyrut: er-Risâletü'l-âlemiyye, 1430/2009, Talâk, 9.

21 Alâüddîn Ebû Bekir b. Mes'ûd el-Kâsânî, Bedâiu’s-sanâi fî tertîbişsşerâi', I-VII, Beyrut: Dâru'l-kütübi'l-ilmiyye, 1406/1986, II, 310.

22 Abdülkerim Zeydân, el-Vecîz fî usûli’l-fikh, Beyrut: Müessesetü’r-risâle, 1427/2006, s. 138.

23 Kâsânî, Bedâi'u-s-sanâi', III, 3.

24 Ebû Muhammed Muvaffakuddîn Abdullah b. Ahmed İbn Kudâme el-Makdisî, el-Muğnî, I-X, Kahire: Mektebetü’lKâhire, 1388/1968, VII, 446; Ebü'l-Kâsım Muhammed b. Ahmed İbn Cüzey el-Kelbî, el-Kavânînül-fikhiyye, yy. ts., 153; Şemsüddîn Muhammed b. Ahmed el-Hatîb eş-Şirbînî el-Kâhirî, Muğni'l-muhtâc ilâ marifeti elfâzi'l-Minhâc, I-VI, Beyrut: Dâru'l-kütübi'l-ilmiyye, 1415/1994, IV, 509; Abdurrahman b Muhammed Şeyhîzâde (Dâmâd Efendi), Mecmau'l-enhur fî şerhi Mülteka'l-ebhur, I-II, Beyrut: Dâru ihyâi't-türâsi'l-Arabî, ts., I, 416. 
Teymiyye’ye (ö. 728/1328) göre ise talâkın şarta bağlanması durumunda kişinin kastı dikkate alınmalıdır. Ona göre bir kimse talâkın vukûunu arzulayarak boşanmayı şarta bağlarsa şartın tahakkuku durumunda talâk vaki olur. Kendini bir fiili yapmaya sevk etmesi yahut bir davranıştan alıkoyması için talâkı şarta bağlayan kimse ise şartın gerçekleşmesi takdirinde eşini boşamış olmaz. Yalnızca yemin kefareti ödemesi gerekir. ${ }^{26}$ Müftîzâde risâlesinde eşkıyaların insanları talâka yemin etmeye zorladıklarından söz etmektedir. Dolayısıyla ikrah doğrudan talâka değil talâkı şarta bağlamaya yöneliktir. ${ }^{27}$ Fakat risâle sahibinin bu bağlamda tartıştığı konular talâkı şarta bağlamaya yönelik ikrah hakkında olmayıp doğrudan talâka zorlamakla ilgilidir. Bu durum risâlenin, ele aldığı problemin çözümüne tam olarak hizmet edemediği izlenimi vermektedir. Bizim kanaatimize göre müellifin böyle davranmasının nedeni Hanefî doktrinde boşamayı şarta bağlamanın da tıpkı talâk gibi mükrihe nispet edilemeyen dolayısıyla mükrehe ait kabul edilen tasarruflardan olmasıdır. ${ }^{28} \mathrm{Bu}$ iki tasarrufun hüküm cihetiyle aynı kategoride yer alıyor olması Müftîzâde’yi bu şekilde davranmaya sevk etmiş olabilir.

Risâle, sahip olduğu fikhî değerin yanı sıra telif edildiği dönemde yaşayan bir Osmanlı âliminin değişen şartlar karşısındaki duruşunu da yansıtan bir özelliğe sahiptir. Nitekim müellifin ikrah altında gerçekleşen talâkın hükmü konusundaki tutumunun bir benzeri, yaklaşık iki asır sonra 1917 yllında yürürlüğe konulan “Osmanlı Hukûk-i Âile Kararnâmesi”nde görülecektir. Kararnâmede asayişin sağlanamadığı durumlarda ortaya çıan olumsuz neticelerin önüne geçmek için ikrah altında gerçekleşen talâk geçersiz kabul edilmiştir. ${ }^{29}$ 19141922 yılları arasında neşredilen Cerîde-i İlmiyye’de yayınlanan Meşîhat Makamı̉na ait fetvalarda da aynı tutumun sergilendiği görülür. ${ }^{30}$

Risâle, Osmanlı Devleti’nin XVII. asırdaki sosyal şartlarını aktarması açısından da ayrı bir öneme sahiptir. Eserin telif edildiği dönemde Aydın yöresi, Anadolu Eyaletine bağlı bir sancak olarak karşımıza çıkmaktadır. Bu dönemde Osmanlı Devleti içerisinde gerek beylerbeyi ve sancakbeyi gibi devlet görevlerinde yer alan gerek halk içinden sivil örgütlenmeyle oluşan pek çok grubun toplum üzerinde tehdit oluşturur hale geldikleri göze çarpar. ${ }^{31}$ XVII. yüzyıl dolaylarında Osmanlı Devleti’nde eşkıyalık olaylarının artışını tetikleyen pek çok etken saymak mümkünse de bunların tümü devletin halk üzerindeki denetim ve otoritesinin zayıflamasıyla ilişkilendirilebilir. ${ }^{32} \mathrm{Bu}$ duruma insanların kolay yoldan mal kazanma hırsı

Takıyyüddin Ebü'l-Abbâs Ahmed b. Abdülhalîm İbn Teymiyye, el-Fetâva'l-kübrâ, I-VI, Beyrut: Dâru'l-kütübi'lilmiyye, 1408/1987, III, 246.

27 Bu durum, mükrihin bir kimseyi mâlik olduğu tüm malları kendisine vermediği takdirde hanımının boşanmış olacağını bildiren bir söz söylemeye zorlayıp o kişinin de ikrahın tesiriyle bu sözleri söylemesi şeklinde tasavvur edilebilir.

İbn Âbidîn, Reddü'l-muhtâr, III, 237.

Hukûk-1 Âile Kararnâmesi, md. 105.

İsmail Cebeci, Cerîde-i İlmiyye Fetvaları, İstanbul: Klasik Yayınları, 2009, s. 163.

Ayşegül Hüseyniklioğlu, Mühimme Defterlerine Göre Osmanl Devletinde Eşklyalık Olayları (1594-1607) (yüksek lisans tezi, 2001), Firat Üniversitesi Sosyal Bilimler Enstitüsü, s. 12, 19.

Akdağ, Mustafa, "Genel Çizgileriyle XVII. yy. Türkiye Tarihi”, Ankara Üniversitesi Tarih Araştırmaları Dergisi, 1996, 
da eklenince toplumun eşkıyalık ve gasp gibi suçlara müptela olması daha da hızlı gerçekleşmiştir. Mühimme defterlerinde yer alan kayıtlardan öğrendiğimiz kadarıyla XVI. ve XVII. yüzyıl dolaylarında Aydın ve yakın çevresinde malların gasp edilmesi, tecavüz ve adam kaçırma gibi olaylara oldukça sık rastlanmaktadır. Nitekim 1605 tarihinde Mehmed Paşa’ya gönderilen hükümde eşkıyanın 400'den fazla atlıyla Aydın çevresindeki halka zulmettiği belirtilmiş, Şeytanoğlu adlı eşkıyanın da etrafına topladığı kişilerle insanları öldürüp mallarını yağma ettiği bildirilerek suçluların derhal yakalanması emredilmiştir. ${ }^{33}$ Aynı şekilde 1595 tarihinde Güzelhisar kadısına gönderilen hükümde bazı bozguncuların ev ve yolları basmak suretiyle adam öldürüp insanların mallarını yağmaladıkları, kadınlara tecavüz ettikleri bildirilerek eşkıyanın yakalanması için serdar ve yiğitbaşı tayin edilmesi emredilmektedir. ${ }^{34}$

Aktarılan bu örneklerden de anlaşıldığı üzere müellifin yaşadığı dönemde aile kurumu tehdit altına girmiş, toplum fertleri neslin emniyetini sağlamada zorluklarla karşılaşır hale gelmiştir. Bir müftü olarak dinî ve hukukî soruların birincil muhatabı olan Muhammed b. Hamza, kendi zâviyesinden İslâm’n benimsediği "kolaylaştırıcı olma” prensibini uygulayarak mükrehin talâkı hakkındaki görüşlerini risâlesinde başarılı bir şekilde sunmuştur.

\section{Risâlenin Tahkîk ve Tercümesi}

\subsection{Risâlenin Tahkîki}

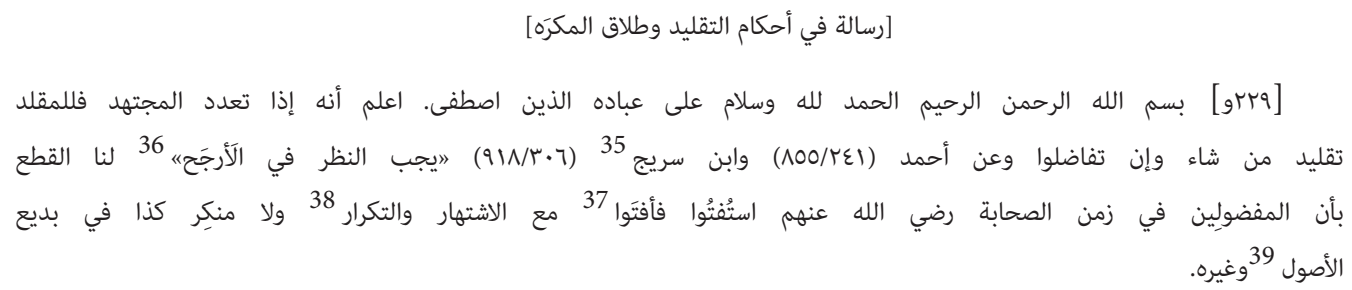

IV, sy. 6-7, s. 204.

33 B.D.A., Mühimme Defterleri, 75, 40/54.

34 B.D.A., Mühimme Defterleri, 73, 532/1163.

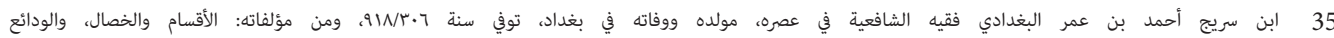

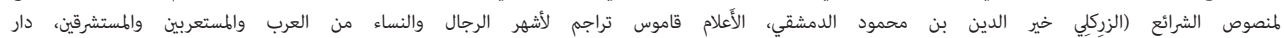

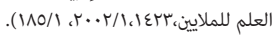

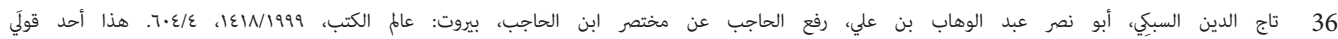

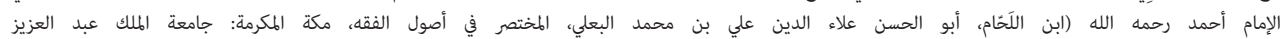

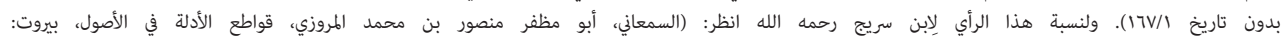

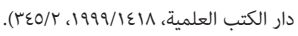

37

38

3939

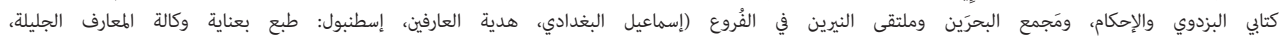


وفي شرح الهداية •ع للشيخ الإمام كمال الدين ابن الهُمَام اع (IIIIIIII)

قد استقر رأي الأصوليين على أن المفتي هو المجتهد وأما 42 غير المجتهد ممن يحفظ أقوال المجتهدين فليس

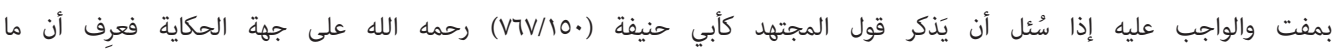

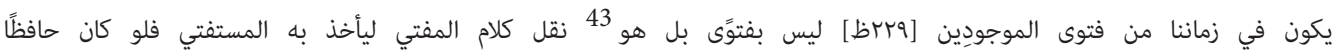

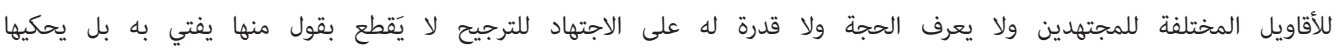

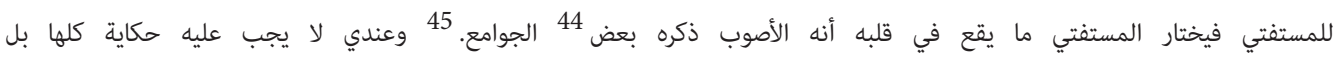

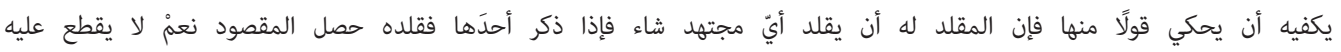
فيقول "جواب سؤالك كذاه بل يقول ״قال أبو حنيفة رحمه الله حكمُ هذا كذاه نعم لو حكى الكل فالأخذ بما يقع في قلبه أنه أصْوب أولى وإلا فالعامي لا عبرة بما يقع في قلبه من صواب الحكم وخطئه.

وعلى هذا إذا استفتى فقيهَين أعني مجتهََين فاختلفا عليه فالأولى 46 أن يَأخذ بما يميل إليه قلبه منهما وعندي أنه

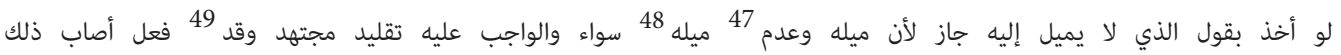
المجتهد أو أخطأ وقالوا ״المنتقل من مذهب إلى مذهب باجتهاد وبرهان آثم يستوجب التعزير 50 فبلا اجتهاد وبرهان أولى" ألى والى

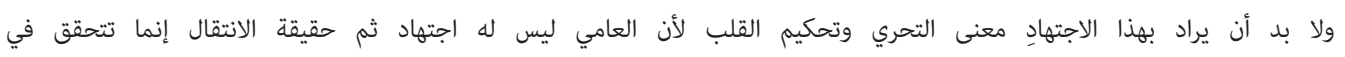

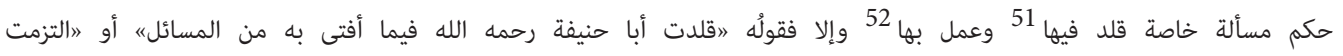

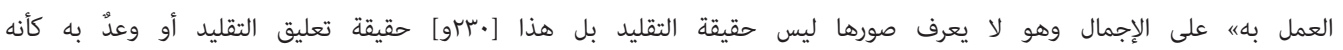
التزم أن يعمل بقول أبي حنيفة رحمه الله فيما يقعُ له من المسائل التي تتعين له في الوقائع فإن أرادوا هذا الالتزام فلا دليل

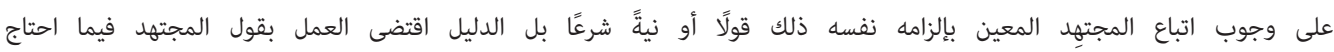

علي بن أبي بكر بن عبد الجليل الفرغاني المرغيناني، توفي سنة سوه /IIV/، ومن مؤلفاته: بداية المبتدي، وشرحُه الهداية في شرح البداية ومختارات النوازل (الأعلام للزركلي ع/17/r).

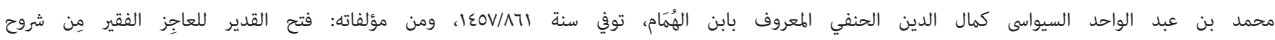

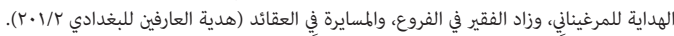

42

43

44

نرى أن كلمة "الجوامع" لها معان متعددة في اصطلاح الفقهاء منها أن شروح العلماء للجامع الصغير للشيباني قد تسمى الجامعَ الصغير خصوصًا إذا كانت

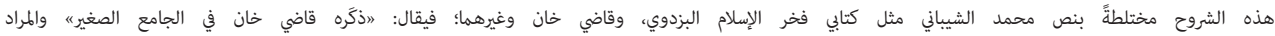

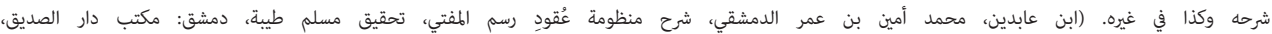

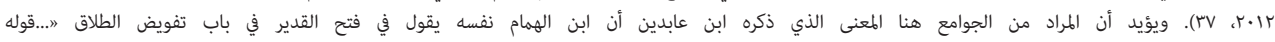

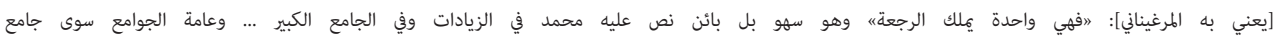

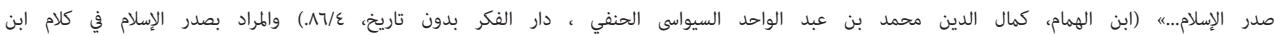

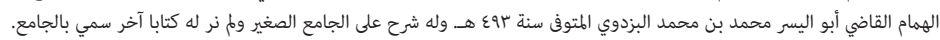

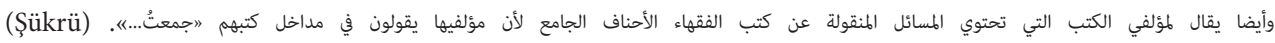

Özen, “Osmanlı Döneminde Fetva Literatürü” Türkiye Araştırmaları Literatür Dergisi, 2005, III, sy. 5, s. 342

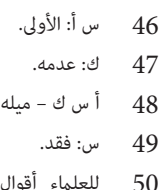

50 للعلماء أقوال متعددة في حق الرجل الذي ينتقل من مذهب إلى إلى آخر، للتفصيل انظر: الزركشي، أبو عبد الله بدر الدين محمد بن عبد الله بن بهادر، البحر

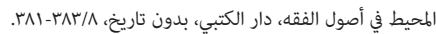

51

52 


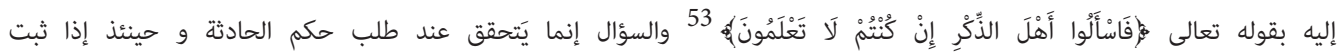
عنده قول المجتهِد وجب عمله به.

والغالب أن مثل هذه إلزامات منهم لكفّ الناس عن تتبُعُ الرخص وإلا أخذ العامي في كل مسألة بقولِ مجتهِهِ قولُه

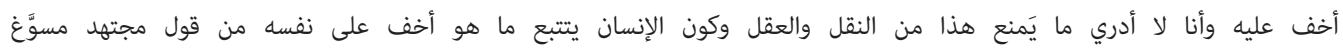

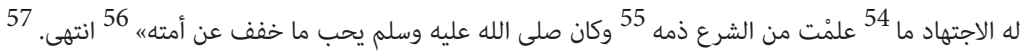
وفي كلام غيره من علمائنا ما يوافق أو يدل [على] 58 ما 59 ذكره المحقق 60 ففي القُنية 61

وينبغي للمفتي أن يختار 62 الأيسر في حق غيره خصوصًا في حق الضعفاء بقوله صلى الله عليه وسلم لعلي ومعاذ

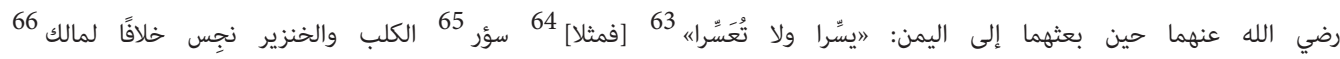
وغيره ولو أفتى بقول مالك جاز.

\section{وفيها أيضًا}

وعن مالك رحمه الله ״البَعُرة طاهرة) فالإغضاء مما 68 فيه البلوى أؤلى تمسكًا بقول من قال بطهارته وفي غيره

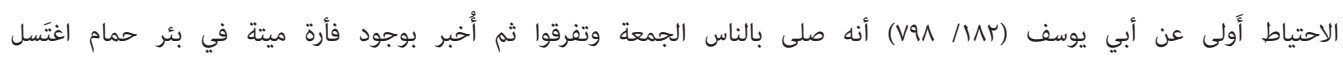

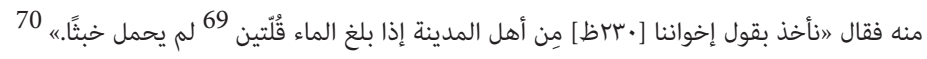
وفيها أيضًا

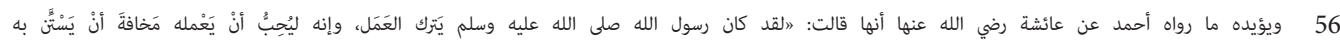

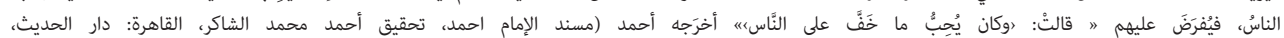

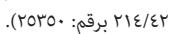
57 58 59 60 60

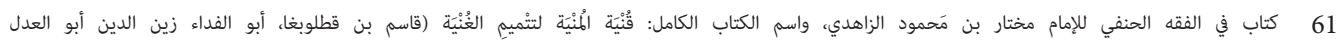

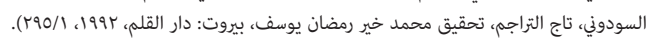
62

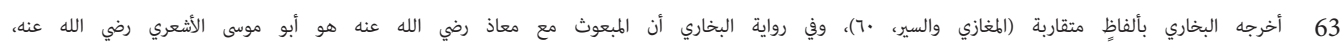

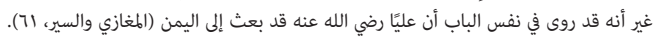

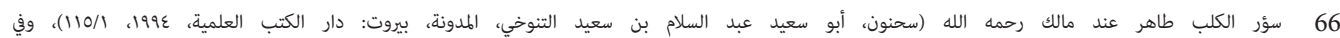

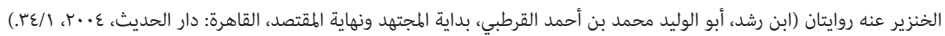

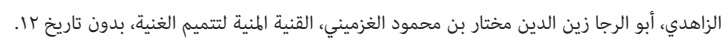

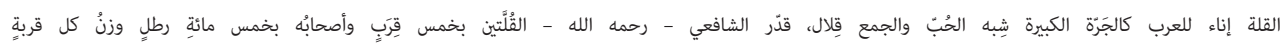

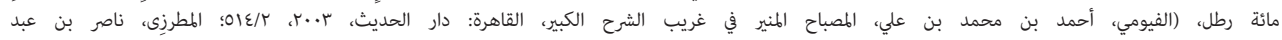

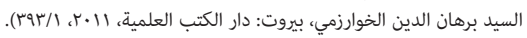




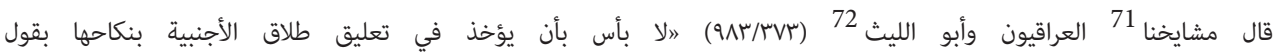

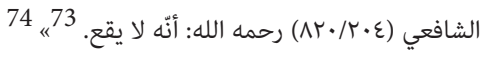

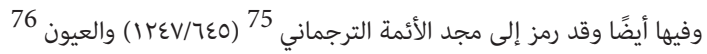

لا بأس أن يُؤخذ هذا بمذهب الشافعي رحمه الله لأن كثيرا من الصحابة في جانبه.

وفي مختارات النوازل 77

رجل علق الطلاق بالتزوج ثم تزوج امرأةً فاستفتى من شافعي المذهب فأفتى على مذهبه أنه لا يقع الطلاق ولم يكن الرجل من أهل الاجتهاد فأخذ قوله ثُم صار فقيهًا على مذهب أبي حنيفة يسعُه المُقام معها. 78

وفي البزازية 79

وعن أصحابنا أنه إذا استفتَى فقيهًا عدلًا فأفتاه ببُطلان اليمين يعني تعليق طلاق الأجنبية بنكاحها حل له العمل بفتواه وإمساكها. فرُوي أوسع من هذا وهو أنه لو أفتاه مفتٍ بالحِل ثم أفتاه آخر بالحرمة بعدما عمل بفتوى الأول فإنه يعمل بفتوى الثاني في حق امرأة أخرى لا في حق الأولى ويعمل بكلتا الفتويين في حادثتين. 80

$$
\text { وفي القُنية }
$$

إذا ظَفر بجنس حقه من مال المديون على صفته فله أخذه بغير رضاه ولا يأخذ الجيد بالرديء وله أخذ الرديء بالجيد ولا يأخذ خلاف جنسه وعند الشافعي رحمه الله له أخذه بقدر قيمته.

وفي المجتبى 81

وما قاله هو الأوسع ويجوز الأخذ به وإن لم يكن مذهبنا فإن الإنسان 82 يعذر عند 83 العمل به عند الضرورة.《 84

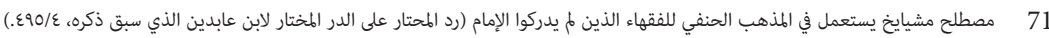

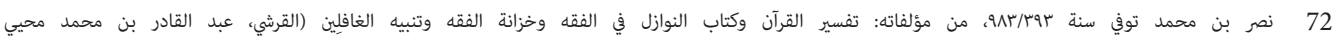

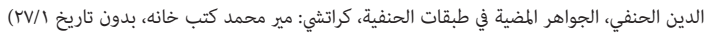

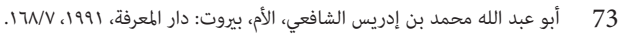

74 75

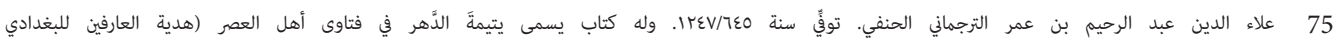

. $07 \cdot / 1$

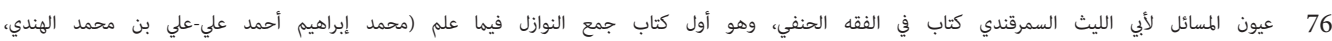

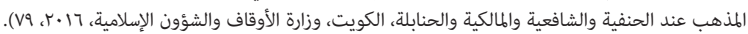

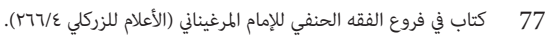

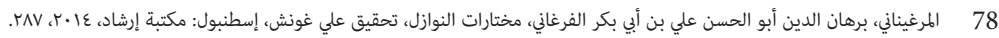

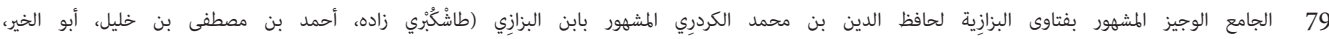

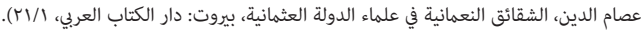

80 8 80

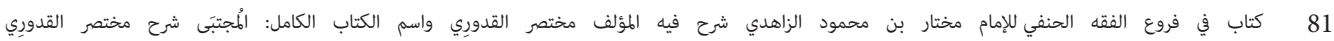

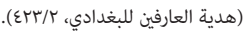

82

83

المجتبى شرح مختصر القدوري للإمام مختار بن محمود الزاهدي ، (رسالة دكتورة غير مطبوعة لمصطفى قاراجه، أعدّ في جامعة نجم الدين أربكان، 84 


$$
\text { وفيه أيضا }
$$

وقد كان [اسبو] بعض مشايخنا وأساتيذنا يُفتُون في هذه المسألة يعني عدَّة ممتدة الطهر بقول مالك رحمه الله عند الضرورة خصوصًا الإمام الزاهد مُنشِئَ النظم نجم الملة والدين الحَفْصي 85 انتهى." 86

$$
\text { وفي البزازِية }
$$

قال العلامة: 87 والفتوى في هذه المسألة على قول مالكٍ رحمه الله انتهى. 88

وتفصيلها هو أنه لو حاضت امرأة مرة أو أكثر ثم طُلّقت فامتد طهرها فعدتها عند أئمتنا والشافعي في الجديد بالقروء فإن وجِدت وإلا تَنتظر إلى سن الإياس فإن أيستْ اعتدَّت بثلاثة أشهر فتزَوجتُ وعند مالك وأحمد تَنتظر تسعة أشهر فإن بان لها حملٌ اعتدَّت بوضعه وإلا اعتدَّت بثلاثة أشهر وتَزوجتْ وكذا إن طُلّقت فحاضت مرة أو مرتين فامتَّْ طهرها وأما إن لم تر دمًا أصلًا أو رأت ولم يستوعب أقل مدة الحيض فعدتها ثلاثة أشهر بالاتفاق ولو بلغت ثلاثين سنةً أو أكثر.《 89 وإذا تقرر هذا فنَقول قد ابتُلي المسلمون وإلى الله سبحانه وتعالى المشتكى في هذا الزمان قليل الخير كثير العدوان

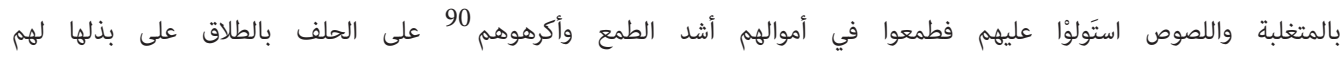
فمنهم من وفى بعهده ولكن ببذل 91 طرِيفه 92 وتليده 93 فأصبح أحوجَ 94 الناس بعد أن كان أغناهم فأخذ يَتكففهم 95

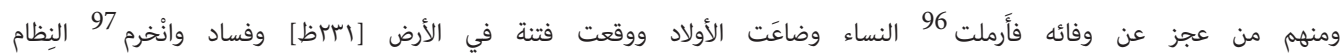
وحدثت أمور عظام من ضُروب المَخازي 98وصنوف المعاصي فمَست الضرورة إلى الأخذ بقول من يقول ببطلان طلاق المكره فإنه وإن كان خلاف قول أئمتنا لكنه قول مجتهَد فيه غير مهجور بدليل قول علمائنا بنفاذ قضاء القاضِي ببطلان

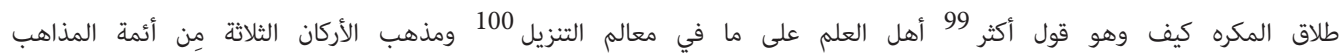

نجم الدين طاهر بن محمد الحفصى أبو المعالى الحنفي المتوفى في حدود سنة .بات وهو استاذ مختار الزاهدي. ومن تصانيفه الفصول في علم الاصول.

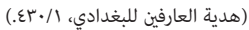
86 87 88

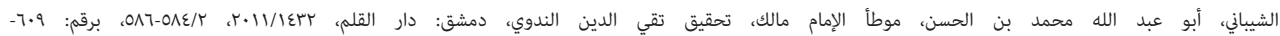

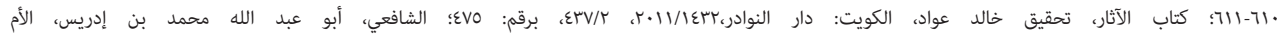

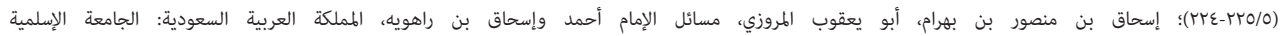

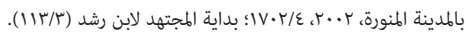
90 91

92 الطارف من الهال المستحدَث، وهو خلاف لـاف التالد والتليد (ابن منظور، أبو الفضل جمال الدين محمد بن مكرم الأنصاري الرويفعي، بيروت: دار صادر، ف عاعا، لسان العرب، "طرفش). 93 94

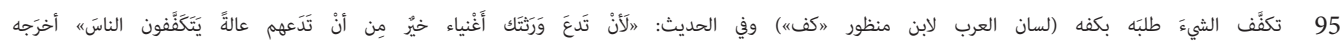
البخاري، (الجنائز بr).

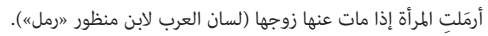

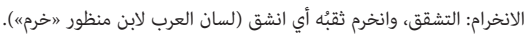

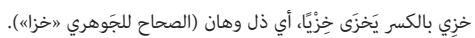
99

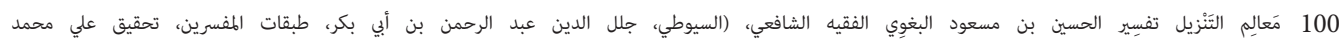
عمر، القاهرة: مكتبة وهبة، 19V7، 19N/ 10N1). 


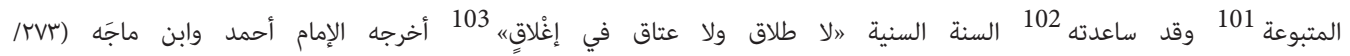
(MV ) والحاكم (0.ع/عاع • (1) وصححه عن عائشة أم المؤمنين رضي الله عنها.

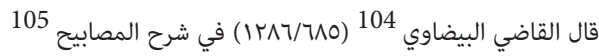

فُُسّر الإغلاق بالإكراه إذ الغالب أن المكرَه يغلق عليه الباب ويضيَّق عليه حتى يأتي المكرَه به وعلى هذا يدل VN) الحديث على أن طلاق المكرَ وعتقَه غير نافذ وإليه ذهب عمر وعلي وابن عمر رضي الله عنهم وبه قال شُرَيح 106

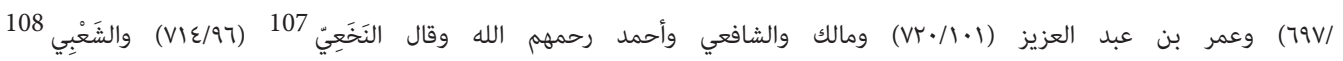
(VYr/I.r. وأبو حنيفة والثوري 109 (VVN/ITI) رحمهم الله: يصح طلاقه دون إقراره لأنه وُجد اللفظ المعتبَر من أهله مصادًِا لمحله ولكن لم يوجد الرضا بثبوت حكمه وهو غير معتبر كما في طلاق الهازل وعتقه وهو ضعيف لأن القصد إلى اللفظ معتبر بدليل عدم اعتبار طلاق من سبق لسانه وهنا القصد إلى اللفظ من نتيجة الإكراه فيكون كالمعدوم بالنسبة إلى [rrr

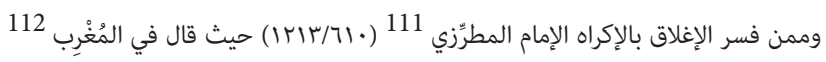

وفي الحديث "لا طلاق ولا عتاق في إغلاق" أي في إكراه لأن المكره مغلق عليه أمره وعن ابن الأعرابي 116 أغلقه على شيء أكرهه 113 (اسب/T/T)

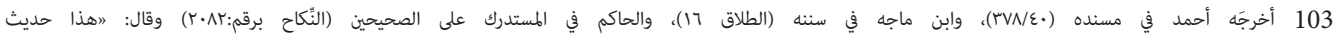
صحيح على شرط مسلم، ولم يخرجاهن.

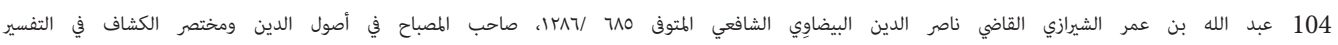

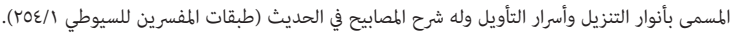

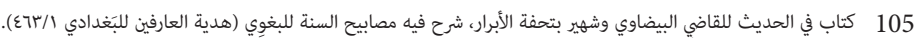

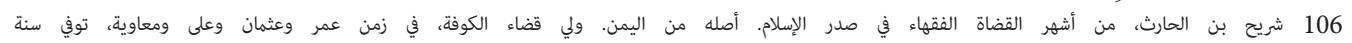

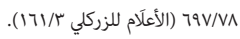
107 إبراهيم بن يزيد أبو عمران النخعي المتوفى سنة 110/97، فقيه العراق من أهل الكوفة ومن أكابر التابعين صلامًا وصدق رواية وحفظًا للحديث (الأعلاًم

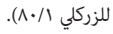

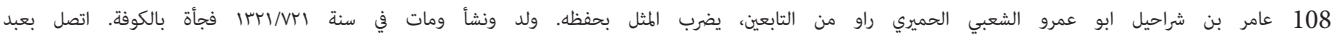

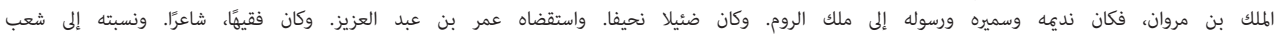

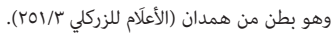

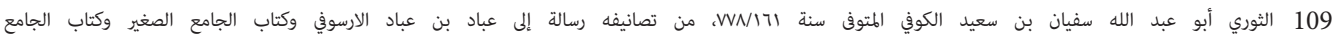

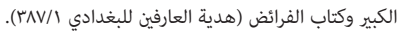

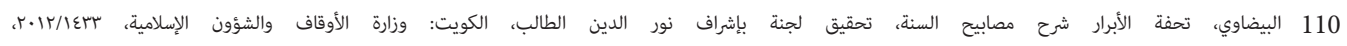
(النكاح 11)

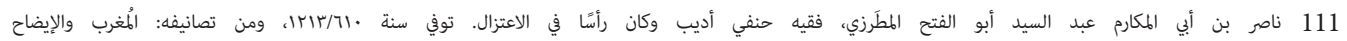

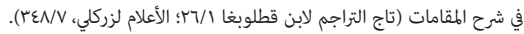

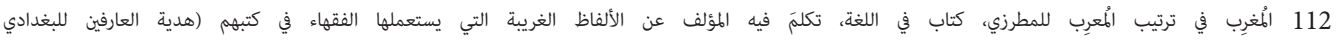

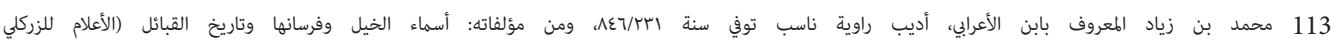
( 1 ( 1 ا 114

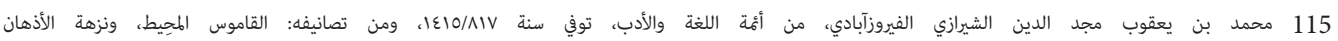

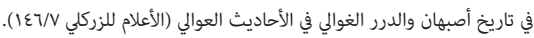


نعم لو لحق قضاء القاضي ببطلانه لكان أحْوط وأحكم لكنه في زماننا متعذر لعدم استجماع شرائط نفاذه على ما لا يخفى على دارِيها واللهُ سبحانه وتعالى أعلم وأحكم.

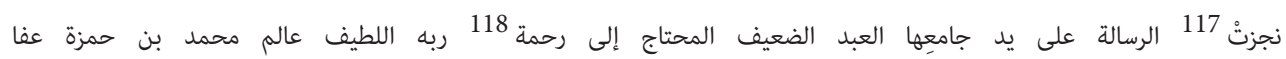

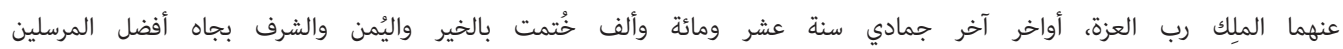
صلَّى الله عليه وعلى آله وصحبه أجمعين وسلم تسليمًا إلى يوم البعث والدين والحمد لله رب العالمين. 119

\subsection{Risâlenin Tercümesi: Taklidin Hükümlerine ve Mükrehin Talâkına Dair Bir}

\section{Risâle}

Rahman ve Rahîm olan Allah'in adiyla

Allah'a hamd, onun seçtiği kullarına selâm olsun.

Bil ki; birden çok müctehidin bulunması durumunda mukallid bunlardan dilediğini taklit edebilir. $\mathrm{Bu}$ müctehidlerin biri diğerinden üstün olsa bile mukallid dilediğini taklit etmekte serbesttir. Ahmed b. Hanbel [ö. 241/855] ve İbn Süreyc’in [ö. 306/918], "Daha üstün olan müctehidi tespit etmek için araştırma yapması gerekir” dedikleri nakledilmiştir.

Bu konuda bizim delilimiz derece bakımından aşağı durumda olan sahâbîlerin kendilerine fetvâ sorulduğunda cevap veriyor olmaları ve bu durumun hiçbir itiraza uğramadan defalarca vukû bulmasıdır. Bedîu'l-usûl ${ }^{120}$ ve başka kitaplarda tercih edilen görüş de budur.

Kemâlüddin İbnü’l-Hümâm, el-Hidâye üzerine yazdığı şerhte şu ifadelere yer verir:

Usûl âlimleri şu konularda fikir birliğine vardılar: 'Müftü, ancak ictihad etme becerisine sahip olan kimseye denir. Kendisi ictihad edemeyip diğer müctehidlerin sözlerini ezberleyen kimse müftü değildir. Böyle birine soru sorulduğunda yapması gereken Ebû Hanîfe gibi bir müctehidin sözünü nakletmektir.' Buradan anlaşıldığ1 üzere günümüzde fetvâ olduğu söylenen sözler hakikatte fetvâ olmayıp soran kişinin öğrenmesi için müftünün sözünü nakletmekten ibarettir. Bu kimse müctehidlerin görüşlerini delillerini bilmeden ezberleyen ancak ictihad edemediği için aralarında tercihte bulunmaya gücü yetmeyen biri ise herhangi bir görüş hakkında kesin ifadelerle fetvâ veremez. Aksine fetvâ soran kimseye [müsteftî] bu görüşleri olduğu gibi aktarır o da kalbinin meylettiği görüşü tercih eder. Câmi ${ }^{121}$ eserlerde

$$
118 \text { ر } 117
$$

119

120 Bedîu'n-nizâm el-câmi beyne kitâbeyi'l-Pezdevî ve'l-İhkâm İbnü's-Sââtî diye bilinen Ahmed b. Ali’nin (ö. 694/1298) telif ettiği fikıh usulü eseridir. Müellif, kitabında Ebü’l-Usr el-Pezdevî ve Âmidînin eserlerini özetleyerek bazı ilavelerde bulunmuştur (Bağdatl, Hediyyetü'l-ârifî̀n, I, 101).

121 Müellifin nakilde bulunduğu İbnü'l-Hümâm "câmi” lafzıyla neyi kastettiğini açıkça belirtmemiştir. Hanefî mezhebinde bu ifadenin iki farklı anlamda kullanıldığı görülür: 1 - Hanefî fakihlerin Muhammed b. el-Hasan eşŞeybânînnin el-Câmiu's-sağîr adlı eseri üzerine yazdıkları șerhler - özellikle el-Câmiu’s-sağîr'in ifadeleri şerhe derç edilip özel olarak gösterilmediyse - "câmi" tabiriyle ifade edilmektedir. Bu nedenle bazı eserlerde Pezdevî ve Kâdıhân 
de böyle zikredilmiştir. Bana göre bu kimsenin fetvâ soran kişiye tüm görüşleri aktarması gerekmez. Aksine bu görüşlerden yalnızca birini nakletmesi yeterlidir. Zira mukallid dilediği müctehidi taklit etmekte serbesttir. Ona bu görüşlerden herhangi birini nakleder ve mukallid de bunu taklit ederse maksat hâsıl olmuş demektir. Tabi ki bunu yaparken fetvâ soran kişiye "Senin sorunun cevabı işte budur" diyerek kesin konuşmaz. Onun yerine, "Ebû Hanîfe meselenin hükmünün bu şekilde olduğunu söyledi” demelidir. Elbette bu kimse soru soran kişiye tüm görüşleri aktarsa ve mukallid de kalbinin meylettiği görüşü tercih etse daha güzeldir. Mukallid böyle davranmadığı yani kalbinin meylettiği görüşü tercih etmediği takdirde yine bir sakıncası olmaz. Çünkü hükmün doğru veya yanlış olduğuna dair sıradan birinin kalbinde oluşan kanaat muteber değildir.

Bu nedenle bir kimsenin fetvâ sorduğu iki fakih yani müctehid ihtilaf ederlerse soruyu soran için evlâ olan kalbinin meylettiği görüşle amel etmesidir. Bana göre kalbinin meyletmediği görüşü alması da caizdir. Çünkü sıradan kimsenin kalbindeki meylin varlığı ve yokluğu birdir. Onun görevi bir müctehidi taklit etmektir. Müctehid ister doğruya ulaşsın ister hata etsin fetvâ soran görevini yerine getirmiştir. 'İctihad ve delile istinâden bir mezhebin dışına çıkarak diğerinin görüşüyle amel eden kimse günahkâr olup tázîri hak ettiğine göre ictihad ve delile dayanmadan bunu yapan kimsenin durumu daha kötüdür' dediler. Burada 'ictihad' kelimesiyle 'araştırma yapma’ ve 'kalbin hakemliğine başvurma' anlamları kast edilmiş olmalıdır. Zira avâm ictihad becerisine sahip değildir. Sonra bilinmeli ki gerçek manada bir mezhebin dışına çıkarak diğerine geçmek [intikâl] ancak daha önce taklide konu olup amel edilen özel bir mesele hakkında söz konusu olur. Mukallidin "Fetvâ verdiği tüm meselelerde Ebû Hanîfe'yi taklit ettim” ya da “... Ebû Hanîfe'ye uymayı iltizâm ettim" gibi tikel suretlerini bilmediği genel ifadeleri gerçek anlamda taklit değildir. Bu ancak taklidi şarta bağlamak yahut taklidi vaat etmektir. Bu sözlerin sahibi olaylar karşısında Ebû Hanîfe'yi taklit etmeyi iltizâm etmiş olur. Eğer (itiraz sahipleri) bir mezhebe tabi olmakla bu iltizâmı kastetmişlerse (bilinmeli ki;) sözle veya sadece niyet ederek belirli bir müctehide bağlanmayı iltizam eden kimsenin bu doğrultuda davranmasını gerektirici dinî bir delil yoktur. Aksine delil, mukallidin yalnızca ihtiyaç duyulduğu durumlarda müctehidin sözüne göre amel etmesini gerektirmektedir. Allah Teâlânın şu buyruğu bu hususa işaret eder: "Eğer

gibi âlimlerin bir meseleyi el-Câmiu’s-sağî̀'de zikrettiği belirtilir. Bu ifadeyle söz konusu müelliflerin el-Câmiu'ssağîr üzerine yazdıkları șerhler kastedilmektedir (İbn Âbidîn, Șerh, s. 36). İbnü'l-Hümâm’ın "câmi" kelimesini bu manada kullanmış olma ihtimalini güçlendiren husus onun Fethu'l-Kadîr adlı eserinde "tefvîzü’t-talâk" konusunu işlerken Ebu'l-Yüsr el-Pezdevînin Câmi adıyla anılan bir eserine atıf yapmasıdır. Pezdevîye ait el-Câmiu's-sağîr şerhi dışında "câmi" diye anılan bir eserin bilgisine ulaşamadık (İbnü'l-Hümâm, Fethu'l-Kadîr, IV, 86). 2 - Hanefî fakihlerin kitaplarından nakledilen bazı meseleleri ihtiva eden eser müellifleri de "câmi" adıyla anılmaktadır. Bu isimlendirmenin nedeni câmilerin nakilde bulundukları kaynaklara işaret etmek için eserlerine "cema’tu/topladım" ifadesiyle başlamalarıdır (Özen, "Osmanlı Döneminde Fetva Literatürü", s. 342). İbnü'l-Hümâm’ın "câmi” kelimesini bu anlamda kullanması da imkân dâhilindedir. Birinci maddede belirttiğimiz anlamı kastetme olasılığı daha güçlü olduğundan tercüme de ona göre yapılmıştır. 
bilmiyorsanız zikir erbâbına sorun." 122 Soru sorma ise ancak (ihtiyaç duyularak) olayın hükmünün talep edilmesi halinde gerçekleşir. Bu durumda soru soran kişi, sözün müctehide ait olduğundan eminse gereğince amel etmesi vacip olur.

Fukahâ genelde bu tür sözleri insanları ruhsatların ardına düşmekten alıkoymak için söylerler. Aksi takdirde avâmdan olan kimseler her bir meselede fetvâsını kolay bulduğu müctehidin görüşünü alırdı. Oysa ben ne aklen ne de naklen buna mâni bir delil görmedim. İnsanın, ictihad etmesi caiz olan bir müctehidin sözünden kendisine kolay gelen bir fetvâyı araştırmasının din tarafından kınandığını bilmiyorum. Hz. Peygamber de ümmetine kolay gelen şeylerden hoşlanırdı.

Âlimlerimizden başkalarının sözlerinde de muhakkik İbnü'l-Hümâm’ın sözlerine uygun ve onu pekiştiren ifadeler vardır. Kunye'de ${ }^{123}$ şu ifadeler yer alır:

Müftünün, insanlar için en kolay uygulanan görüşü seçmesi gerekir. Özellikle de zayıf kimseler hakkında tavrı bu olmalıdır. Çünkü Hz. Peygamber, Hz. Ali [ö. 40/661] ve Muâz’ı [ö. 17/638] Yemen’e gönderirken, "Kolaylaştırın, zorlaştırmayın” ${ }^{124}$ buyurmuştur. Örneğin [bize göre] köpek ve domuzun artığı necistir. İmam Mâlik [ö. 179/795] ve bazı fakihler buna muhaliftir. Müftünün bu meselede Mâlik'in kavline göre fetvâ vermesi caizdir.

\section{Yine Kunye’de geçtiğine göre;}

İmam Mâlik ve başkalarından toynaklı hayvanlara ait dışkıların temiz olduğu rivayet edilmiştir. Bu görüşe istinâden toynaklı hayvanların sakınılması zor olan dışkıları hakkında müsâmaha göstermek daha münasiptir. Sakınmanın mümkün olduğu durumlarda ise ihtiyata göre davranmak uygun olur. Rivayete göre, Cuma namazını kıldıran Ebû Yusuf’a [ö. 182/798] namaz dağıldıktan sonra, guslettiği su kuyusunda bir fare ölüsünün bulunduğu haber verilmiş. Ebû Yusuf, "Biz de Medineli kardeşlerimizin görüşüyle amel ederiz. Onlara göre su iki kulle ${ }^{125}$ miktarına ulaştı̆̆ında necis olmaz" demiştir.

Yine aynı eserde şöyle denilir:

122 16/en-Nahl: 43.

123 Hanefî mezhebinin furû fikıhla ilgili görüşlerini içeren Kunyetü'l-münye li tetmîmi’l-Ğunye adlı eser genellikle Zâhidî diye anılan Muhtâr b. Mahmud’a (ö. 658/1260) aittir (Ebü'l-Adl Zeynüddîn Kâsım b. Abdullah es-Sûdûnî İbn Kutluboğa, Tâcü't-terâcim [nşr. Muhammed Hayr Ramazan Yusuf], Dımaşk: Dâru'l-kalem, 1412/1992, I, 295.)

124 Ebû Abdullah Muhammed b. İsmail el-Cưfî̀ el-Buhârî, el-Câmiu'l-müsnedü's-sahîhu'l-muhtasar min umûri Rasûlillah sallallahu aleyhi ve sellem ve sünenihi ve eyyâmih (nşr. Muhammed Züheyr b. Nâsır). I-IX, Beyrut: Dâru tavki'n-necât, 1422/2001, Meğâzî, 60 .

125 Kulle, Arapların kullandığı bir tür büyük kaptır (Feyyûmî, el-Misbâhu’l-münîr, s. 321). 
Iraklı meşâyihimiz ${ }^{126}$ ve Ebü'l-Leys [ö. 393/983] ${ }^{127}$ henüz evlenilmemiş bir kadının talâkını onunla evlenme şartına bağlama ( a $^{\prime} l \hat{\imath} k$ ) konusunda Şâfiînin talâkın vâki olmayacağı yönündeki görüşünü almakta beis yoktur demişlerdir.

Yine Kunye'de Mecdüleimme et-Tercümânî [ö. 645/1247] ${ }^{128}$ ve Uyûn ${ }^{129}$ adlı eserin rumuzu zikredilerek (talâkı şarta bağlama/ ta'lîk hususunda) şu ifadelere yer verilir:

Bu konuda Şâfiî̀nin görüşüne göre amel etmekte bir beis yoktur. Zira birçok sahâbî onunla aynı fikirdedir.

Muhtârâtü’n-nevâzil ${ }^{130}$ adlı eserde şöyle geçmektedir:

Boşanmayı evlenme şartına bağlayan kişi, bir kadınla evlendikten sonra Şâfiî mezhebine mensup bir müftüden durumuyla ilgili fetvâ sorsa, müftü de ictihad ehli olmayan bu kişiye kendi mezhebinde benimsenen, talâkın vaki olmayacağ 1 görüşüne göre fetvâ verip bu kişi müftünün kavliyle amel ettikten sonra Ebû Hanîfe’nin mezhebinde bir fakih haline gelse evlendiği kadınla evliliğine devam edebilir.

Bezzâziye'de ${ }^{131}$ de şu ifadeler yer alır:

Ashâbımızdan nakledildiğine göre bu (boşamayı evlenme şartına bağlayan) kimsenin fetvâ sorduğu âdil bir fakih yeminin - henüz evlenilmemiş kadının talâkını onunla evlenme şartına bağlamayı kastediyor - geçersiz olduğuna fetvâ verse bu fakihin fetvâsıyla amel ederek kadını (nikâhında) tutabilir. Bundan daha müsamahalı ifadeler de aktarılmıştır. Şöyle ki; bu durumda olan birine bir müftü evliliği sürdürmesinin helâl olduğu yönünde fetvâ verip amel ettikten sonra başka bir müftü bu davranışın haram olduğunu söylemiş olsa ikinci müftünün fetvâsıyla başka bir kadın hakkında amel edebilir. Bu durumda iki ayrı olayda iki farklı fetvâyla amel etmiş olur.

Kunye’de şu ifadeler zikredilmektedir:

126 "Meşâyih" tabiri Ebu Hanîfe ile görüşmemiş olan Hanefî fakihler hakkında kullanılan bir terimdir (İbn Âbidîn, Reddü'l-muhtâr, IV, 495).

127 Hanefî fakih Ebü’l-Leys es-Semerkandî Nasr b. Muhammed’in telif ettiği eserler arasında Kitâbün-nevâzil, Tenbîhü’lğâfilîn, Uyûnü’l-mesâil ve Hizânetül-fikh gibi kitaplar yer alır (Kureşî, el-Cevâhiru'l-mudiyye, I, 27).

128 Hanefî fakihlerinden olan Aläüddîn Abdürrahim b. Ömer et-Tercümânîye Yetîmetü'd-dehr fi fetâvâ ehli'l-asr adlı bir eser nispet edilir (Bağdatl, Hediyyetü'l-ârifîn, I, 560).

129 Ebü’l-Leys es-Semerkandînin, Ebû Hanîfe ve öğrencilerine ait zâhirü’r-rivâye dışındaki görüşleri topladığı önemli bir eserdir (Bağdatlı, Hediyyetül-ârifîn, II, 490; Yazıcı, "Semerkandî, Ebü’l-Leys”, DİA, XXXVI, 473).

130 Muhtârâtün-nevâzil, Hanefî fakih Ali b. Ebû Bekir el-Merğînânîye aittir (Ebû Gays Muhammed Hayrüddîn b. Mahmud ed-Dımaşkî ez-Ziriklî, el-A'lâm, kamûsü terâcim li-eşheri'r-ricâl ve’n-nisâ minél-Arab ve'l-müstarebîn ve'lmüsteşrikîn, I-VIII, Beyrut: 1423/2002, IV, 266).

131 el-Fetâva'l-Bezzâziyye olarak da bilinen eserin asıl adı el-Câmiu’l-vecîz'dir. Hanefî fakih İbnü'l-Bezzâzî Hâfizüddin Muhammed el-Kerderî̀ye (ö. 827/1414) aittir (Taşköprîzâde, eş-Şekâiku’n-Numâniye, I, 21). 
Borçlusunun borcun konusuyla aynı cins ve sıfattaki malını gören kişi bu malı onun rızası olmadan alabilir. Kendi hakkının değeri (kıymet) düşük olduğu takdirde borçlusunun değeri yüksek olan malını alamaz fakat kendisinin değeri yüksek olan hakkına karşın borçlusunun düşük değerdeki malını alabilir. Kendi hakkıyla aynı cinsten olmayan malları da alamaz. Şâfiîye göre ise aynı kıymette olduğu takdirde farklı cinsten mallarını da alabilir.

Müctebâ'da ${ }^{132}$ bu konuyla ilgili şöyle denilir:

Şâfiî̀nin görüşünü uygulamak daha münasiptir. Her ne kadar bizim mezhebimizin görüşü bu yönde olmasa da fetvâ buna göre verilebilir. Çünkü insan zaruret hallerinde bu görüşe göre amel edecek olsa mazur görülür.

Yine Müctebâ'da şu ifadeler yer alır:

Meşâyih ve üstatlarımızdan bir kısmı bu meselede - âdet görebilecek yaşta olmasına rağmen âdet görmeyen kadının iddetini kastediyor - zaruret durumlarında İmam Mâlik'in kavliyle fetvâ verirlerdi. Özellikle de zâhid imam, şeriatın ve dinin yıldızı Hafsî [ö. 620/1223] ${ }^{133}$ bu konuda Mâlik’in görüşüne göre fetvâ verirdi.

Bezzâziye'de de, “Allâme 134 'Bu konuda fetvâ Mâlik'in kavline göredir' dedi” ifadesi yer almaktadır.

Bu konunun tafsilatı şu şekildedir; bir kadın bir defa ya da daha fazla âdet gördükten sonra boşanmış ve temizlik döneminde geçen süre de uzun sürmüş olursa imamlarımız ve Şâfiînnin kavl-i cedîdine göre boşanma iddetini kurû' ${ }^{135}$ ile bekler. Eğer kurû' ile beklemek mümkün değilse bu takdirde âdetten kesilme [iyâs] yaşına kadar bekleyip âdetten kesildiğinde üç ay iddet bekleyerek dilerse yeniden evlenebilir. Mâlik ve Ahmed’e göre ise bu durumdaki kadın dokuz ay bekler, eğer bu süreçte hâmile olduğu anlaşılırsa iddeti doğumla sona erer. Hamilelik durumu söz konusu değilse bu takdirde üç ay daha iddet bekleyip sonrasinda dilerse evlenebilir.

Temizlik süresi, kadının boşanıp bir veya iki kez âdet görmesi sonrasında uzamış olsa yine aynı hükümler cari olur. Fakat bu kadın hiç kan görmemiş yahut asgari âdet süresinden

132 el-Müctebâ, Muhtâr b. Mahmud ez-Zâhidî (ö. 658/1260) tarafından Ahmed b. Ebû Bekir el-Kudûrîye ait el-Muhtasar üzerine yapılan şerhin adıdır (Bağdatlı, Hediyyetü'l-ârifîn, II, 423).

133 Tam ismi Necmüddîn Tâhir b. Muhammed el-Hafsî olan bu fakih daha ziyade "Ebü’l-Meâlî” lakabiyla bilinir. Zâhidînin hocaları arasında yer alan el-Hafsîye el-Fusûl fî ilmi'l-usûl adlı bir eser nispet edilir (Bağdatlı, Hediyyetü’lârifîn, I, 430).

134 “Allâme” ifadesiyle alıntı yapılan eserin müellifi Hâfızüddîn Muhammed b. Muhammed el-Kerderî (İbnü’l-Bezzâzî) kastedilmektedir.

135 "Kur" kelimesi lügatte kadınların hem adet hem de temizlik dönemini ifade etmek için kullanılır. Kur'ân’da Bakara sûresi 228. ayette yer alan bu kelimeyle Hanefî hukukçulara göre hayız, Şâfiîlere göre ise temizlik dönemi kast edilmiştir (Mutarrizî, el-Muğrib, s. 405; Feyyûmî, el-Misbâhu'l-münîr, s. 313). 
daha az görmüş ise otuz yaşında veya daha ileri bir yaşta olsa bile iddetinin üç ay olduğu hususunda ittifak edilmiştir.

Bu zikredilen hususlar netleştiğine göre deriz ki; şu hayrı az, zorbası, hırsızı bol zamanımızda Müslümanlar çeşitli imtihanlardan geçmekteler. Onların başlarına çökmüş, mallarına göz dikmiş bu eşkıyalar sahip oldukları malları ellerinden almak için onları talâk üzerine yemin etmeye zorlamaktalar. Bazı Müslümanlar nikâhlarını korumak adına ellerinde eski yeni ne varsa hepsini bu kimselere kaptırdı. Sonra da insanların en zenginiyken birden en muhtacı haline gelip onlara el açar oldu. Kimileri ise ettiği yeminin gereğini yerine getiremedi ve kadınlar dul kalıp çocuklar zâyi oldu. Böylece yeryüzünde fesat vukû bulup düzen bozuldu, nice rezil işler ve günahlar türedi. Bu nedenle ikrah altında gerçekleşen talâkın geçersiz olduğuna hükmeden fakihlerin görüşleriyle amel etme zarureti doğdu. Çünkü bu görüş her ne kadar imamlarımızın kavline muhalif olsa da neticede ictihadla elde edilmiş olup tamamen terkedilen bir görüş değildir. Bu tutumun külliyen terk edilmediğinin delili, ulemâmız nazarında hâkimin mükrehin talâkının batıl olduğuna dair verdiği hükmün geçerli olmasıdır. ${ }^{136}$

Bu görüşü nasıl görmezden geliriz? Oysa bu, Me âlimü’t-tenzîl'de ${ }^{137}$ geçtiği üzere ilim ehlinin çoğunluğunun görüşüdür. Ayrıca kendisine uyulan üç mezhebin imamları da bu kanaattedir. Sünnet-i seniyye de bu hükmü desteklemektedir. İmam Ahmed, İbn Mâce [ö. 273/887] ve Hâkim'in [ö. 405/1014] aktardığı bir rivayette, "Baskı [iğlâk] altında gerçekleşen talâk ve azat geçersizdir" 138 buyurulur. Hâkim bu hadisi Hz. Âişe'den rivayet edip sahih olduğunu belirtmiştir.

Kadı Beyzâvî [ö. 685/1286] ${ }^{139}$ Şerhu'l-Mesâbîh’te şu ifadeleri zikreder:

Hadiste yer alan 'iğlâk' kelimesinin 'ikrâh' anlamına geldiği söylenmiştir. Çünkü ikrah altındaki kişi zorlandığı fiili yerine getirene dek kapılar ardında tutulup [yŭglaku aleyhil-bâb] baskıya maruz bırakılır. Buradan çıkan sonuca göre hadis mükrehin yaptığı talâk ve köle azadının geçersiz olduğunu ifade etmek üzere söylenmiştir. Hz. Ömer [ö. 624/644], Hz. Ali, İbn Ömer [ö. 73/692], Şüreyh [ö. 80/699], Ömer b. Abdülaziz [ö. 101/720], Mâlik, Şâfiî ve Ahmed de bu görüşü benimsemişlerdir.

136 Hanefîlerde ikrah altında gerçekleșen boşama geçerlidir. Fakat hâkimin bu talâkın batıl olduğuna hükmetmesi durumunda geçersiz kabul edilir (İbnü'l-Hümâm, Fethu'l-Kadîr, VII, 302).

137 Meâlimü't-tenzîl, Hüseyin b. Mesîud el-Begavîye (ö. 516/1122) ait Kurân tefsiridir (Ebü’l-Fazl Celâlüddîn Abdurrahman b. Ebû Bekir eş-Şafîî es-Süyûtî, Tabakâtü̈l-müfessirîn [nşr. Ali Muhammed Ömer], Kahire: Mektebetü Vehbe, 1396/1976, I, 158).

138 İbn Mâce, Talâk, 16.

139 Kâdı Beyzâvî Nâsıruddîn Abdullah b. Ömer eş-Şirâzî, Şâfiî fukahâsından olup tefsire dair yazdığı Envâru't-tenzîl ve esrâru't-te’vîl adlı eseri ve (Begavî̀nin telif ettiği) Mesâbîhu's-sünne üzerine yazdığı șerh (Tuhfetü'l-ebrâr) bilinen eserlerindendir (Süyûtî, Tabakâtü’l-müfessirîn, I, 254). 
Nehaî [ö. 96/815], ${ }^{140}$ Şa âî [ö. 104/722], ${ }^{141}$ Ebû Hanîfe ve Sevrî [ö. 161/778] ${ }^{142}$ ise ikrah altındaki kişinin ikrarlarının geçersiz fakat talâkının sahih olduğunu söylemişlerdir. Zira talâk sözcügü, ehliyet sahibi bir kimseden muteber ve konusuna uygun bir şekilde sâdır olmuştur. Şu kadar var ki bu sözün sahibinin hükmün sübûtuna rızası yoktur. Rızanın yokluğu ise şaka yapmak kastıyla hanımını boşayan veya bu niyetle köle azat eden kimsenin durumunda olduğu gibi dikkate alınmaz.

Bu zayıf bir görüştür. Çünkü dil sürçmesiyle talâk lafzını söyleyen kimsenin bu fiilinin talâk kabul edilmiyor olmasından da anlaşıldığı üzere, talâkın gerçekleşmesi için lafzın özellikle kastedilmesi gereklidir. İkrah altında gerçekleşen talâkta lafız her ne kadar kasıtlı söylenmiş olsa da bu kasıt ikrahın etkisinde ortaya çıktığı için yok hükmündedir.

Hadiste geçen "iğlâk" kelimesini "ikrah" olarak açıklayan bir diğer kişi de İmam Mutarrizî̀dir. ${ }^{143}$ Muğrib'de şöyle demektedir:

Hadiste "Baskı [iğlâk] altında gerçekleşen talâk ve azat geçersizdir" buyurulmaktadır. İğlâk, ikrah anlamına gelir. Çünkü ikrah altındaki kimsenin işinin önü kapatılmıştır [muğlakun aleyhi emruhû]. İbnü’l-Árâbînin [ö. 231/846] 144 “Onu bir şeye zorladı" [eğlakahû ala şey] sözünün "Ona ikrahta bulundu” anlamına geldiğini söylediği nakledilir. "İğlâk ikrahtır" diyen el-Kâmûs sahibi ${ }^{145}$ de bu kelimenin "ikrah" manasına geldiğini söyler.

Elbette ki ikrah altında hanımını boşayan kimsenin bu fiilinin geçersiz olduğuna dair bir de hâkim kararı eklenecek olursa ihtiyata daha uygun ve sağlam olur. Fakat ehline malum olduğu üzere geçerlilik şartları oluşmadığından bu durum zamanımızda zor vukû bulur.

Allah Teâlâ en iyi ve en doğru şekilde bilendir.

Risâle, lütfu bol olan Rabbinin rahmetine muhtaç, zayıf kul, âlim Muhammed b. Hamzảnın eliyle 1110 Cemâziyelâhir'de hitâma erdi. Allah ona ve babasına rahmet etsin. Peygamberlerin en üstününün şerefine; hayır, bereket ve izzetle son buldu. Allah Hz. Peygamber'e, âline ve ashabina hesap gününe dek salât ve selam eylesin. Âlemlerin rabbi olan Allah'a hamdolsun.

140 Ebû İmrân İbrahim b. Yezîd en-Nehaî tâbiûnun büyüklerinden ve Irak fukahâsındandır (Ziriklî, el-A'lâm, I, 80).

141 Ebû Amr Âmir b. Şerâhîl eş-Şa 'bî el-Kûfî, hem tâbiûnun fakihlerindendir hem de hadis râvisidir (Ziriklî, el-A‘lâm, III, 251).

142 Kûfe'de yaşayan Ebû Abdullah Süfyân b. Saîd es-Sevrînin adına nispet edilen fikhî bir mezhep bulunmaktadır. Telif ettiği eserler arasında el-Câmiu's-sağîr, el-Câmiu'l-kebîr ve Kitâbü'l-Ferâiz zikredilir (Bağdatlı, Hediyyetü'l-ârifîn, I, 387).

143 Nâsır b. Ebü'l-Mekârim Ebü’l-Feth el-Mutarrizî, Harezmli Hanefî fakihi ve dilcidir. Mu'tezile’nin reisi olduğu nakledilmiştir. el-Muğrib fî tertibi'l-Mu'rib ve el-Îdâh fî şerhi'l-Mukaddimât telif ettiği eserler arasında zikredilir (İbn Kutluboğa, Tâcü't-terâcîm, I, 26; Ziriklî, el-A'lâm, VII, 348).

144 Ebû Abdullah Muhammed b. Ziyâd daha ziyade İbnü'l-Árâbî ismiyle bilinir. Kendisine Esmâül-hayl ve fürsânihâ ve Târîhül-kabâil gibi eserler nispet edilmiştir (Ziriklî, el-A'lâm, VI, 131).

145 Bu ifadeyle el-Kâmûsü’l-muhît sahibi ünlü dilci Muhammed b. Ya‘kûb el-Feyyûmî (ö. 817/1415) kastedilmiștir. 


\section{Kaynaklar}

Ahmed b. Hanbel, Ebû Abdullah Ahmed b. Muhammed b. Hanbel eş-Şeybânî. el-Müsned (nşr. Ahmed Muhammed Şâkir). I-VIII, Kahire: Dâru'l-hadîs, 1416/1915.

Akdağ, Mustafa, “Genel Çizgileriyle XVII. yy. Türkiye Tarihi.” Ankara Üniversitesi Tarih Araştırmaları Dergisi, 1996, IV, sy. 6-7, s. 201-47.

Bağdatlı İsmail Paşa. Hediyyetü'l-ârifîn esmâü'l-müellifîn ve âsâru'l-musannifîn. I-II, Beyrut: Dâru ihyâi'ttürâsi'l-Arabî, 1370/1951.

-------. İzâhu'l-meknûn. I-IV, Beyrut: Dâru ihyâi't-türâsi'l-Arabî, ts.

Başbakanlık Devlet Arşivleri Genel Müdürlüğü Osmanlı Arşivi Daire Başkanlığı, 73. ve 75. Mühimme defterleri.

el-Beyzâvî, Nâsırüddîn Ebû Saîd Abdullah b. Ömer. Tuhfetü’l-ebrâr şerhu Mesâbîhi's-sünne (nşr. Nureddin Tâlib - v.dğr.). I-III, Kuveyt: Vizâretü'l-evkâf ve'ş-şuûni'l-İslâmiyye, 1434/2012.

el-Bezzâzî, Hâfizüddîn Muhammed b. Muhammed el-Kerderî el-Hârizmî. el-Câmiu'l-vecîz (el-Fetâva'lBezzâziyye). I-VI, Fetâvâ-yı Hindiyye’nin IV-VI cüzlerinin kenarında), Beyrut: Dâru’l-fikr, ts.

Bilmen, Ömer Nasûhî. Büyük Tefsir Tarihi, İstanbul: Bilmen Yayınları. 1971.

el-Buhârî, Ebû Abdullah Muhammed b. İsmail el-Cưfî. el-Müsnedü's-sahîhü'l-muhtasar min umûri Rasûlillah sallallahu aleyhi ve sellem ve sünenihi ve eyyâmih (nşr. Muhammed Züheyr b. Nâsır). I-IX, Beyrut: Dâru tavki'n-necât, 1422/2001.

Bursalı Mehmet Tahir. Osmanlı Müellifleri (haz. A. Fikri Yavuz - İsmail Özen). I-III, İstanbul: Meral Yayınları, ts.

Cebeci, İsmail. Cerîde-i İlmiyye Fetvaları. Klasik Yayınları, 2009.

el-Cevherî, Ebû Nasr İsmail b. Hammâd. es-Sihâh (Tâcüll-lüğa) (nşr. Muhammed Zekeriya Yusuf). I-VI, Beyrut: Dâru'l-ilm li'l-melâyîn, 1410/1990.

Cici, Recep. Bir Osmanlı Fakihi Âlim Muhammed b. Hamza'nın Fıııh Risâleleri. Bursa: Emin Yayınları, ts.

Demirci, Seyda. Hacı Emirzâde Muhammed b. Hamza el-Aydınînin Hayatı, Eserleri ve Günlük Hayata Dair Bazı Risâlelerinin Tanıtımı (yüksek lisans tezi, 2014). Marmara Üniversitesi Sosyal Bilimler Enstitüsü.

el-Feyyûmî, Ebü'l-Abbâs Hatîbüddehşe Ahmed b. Muhammed b. Ali el-Hamevî. el-Misbâhu'l-münîr fî ğarîbiş̧-Şerhi'l-kebîr. Kahire: Dâru'l-hadîs, 1429/2008.

Emîr Pâdişâh, Muhammed Emîn b. Mahmud el-Hüseynî el-Buhârî el-Mekkî. Teysîru't-Tahrîr (nşr. Mustafa el-Bâbî el-Halebî). I-IV, Beyrut: Dâru'l-kütübi'l-ilmiyye, 1351/1932.

Hüseyniklioğlu, Ayşegül. Mühimme Defterlerine Göre Osmanlı Devleti’nde Eşkıyalık Olayları (1594-1607) (yüksek lisans tezi, 2001), Frrat Üniversitesi Sosyal Bilimler Enstitüsü.

İbn Âbidîn, Muhammed Emîn b. Ömer ed-Dımaşkî. Şerhu Manzûmeti ukûdi resmi'l-müftî (nşr. Müsellem Taybe). Dımeşk: Mektebetü dâri's-sıddîk, 1433/2012.

------. Reddü'l-muhtâr ale'd-dürri'l-muhtâr. I-VI, Beyrut: Dâru'l-fikr, 1412/1992.

İbn Cüzey, Ebü'l-Kâsım Muhammed b. Ahmed el-Kelbî el-Gırnâtî. el-Kavânînüll-fikhiyye. yy. ts.

İbn Emîr Hâc, Ebû Abdullah Şemsüddîn Muhammed b. Muhammed el-Halebî. et-Takrîr ve’t-tahbîr. I-III, Beyrut: Dâru'l-kütübi'l-ilmiyye, 1983/1403.

İbn Kutluboğa, Ebü'l-Adl Zeynüddîn Kâsım b. Abdullah es-Sûdûnî. Tâcü't-terâcim (nşr. Muhammed Hayr Ramazan Yusuf). Dımaşk: Dâru'l-kalem, 1412/1992.

İbn Kudâme, Ebû Muhammed Muvaffakuddîn Abdullah b. Ahmed el-Makdisî. el-Muğnî. I-X, Kahire: Mektebetü’l-Kâhire, 1388/1968. 
İbn Mâce, Ebû Abdullah Muhammed b. Yezîd İbn Mâce el-Kazvînî, es-Sünen (nşr. Şuayb el-Arnaût - Âdil Mürşid), I-V, Beyrut: er-Risâletü'l-âlemiyye, 1430/2009.

İbn Manzûr, Ebü’l-Fazl Cemâlüddîn Muhammed b. Mükerrem b. Ali el-Ensârî. Lisânu’l-Arab. I-XV, Beyrut: Darü sâdır, 1414/1994.

İbn Rüşd, Ebü'l-Velîd Muhammed b. Ahmed b. Muhammed el-Kurtubî. Bidâyetü’l-müctehid ve nihâyetü'lmuktesid. I-IV, Kahire: Dâru'l-hadîs, 2004.

İbnü'l-Hümâm, Kemâlüddîn Muhammed b. Abdülvâhid es-Sivâsî el-İskenderî. Fethu'l-Kadîr şerhü’lHidâye. I-X, Beyrut: Dâru'l-fikr, ts.

İbnü'l-Lahhâm, Ebü'l-Hasan Alâüddîn Ali b. Muhammed ed-Dımaşkî. el-Muhtasar fî usûli’l-fikh (nşr. Muhammed Mazhar Bekâ). Mekke: Camiatü'l-melik Abdülazîz, ts.

İbn Teymiyye, Ebü'l-Abbâs Takıyyüddîn Ahmed b. Abdülhalîm el-Harrânî. el-Fetâva'l-kübrâ. I-VI, Beyrut: Dâru'l-kütübi'l-ilmiyye, 1408/1987.

İshak b. Mansûr el-Kevsec, Ebû Ya'kûb el-Mervezî. Mesâilü’l-İmâm Ahmed ve İshâk b. Râhûye. I-IX, Medine, el-Câmiatü'l-İslâmiyye, 1422/2002.

el-Kâsânî, Alâüddîn Ebû Bekir b. Mes'ûd. Bedâiu’s-sanâi fî tertîbişs-şerâi'. I-VII, Beyrut: Dâru'l-kütübi'lilmiyye, 1406/1986.

Kaya, Eyüp Said. “Taklid”, DİA, XXXIX, 461-465.

el-Kureşî, Ebû Muhammed Muhyiddîn Abdülkâdir b. Muhammed el-Misrî. el-Cevâhiru'l-mudiyye fî̀ tabakâti'l-Hanefiyye (nşr. Mîr Muhammed Karaçi). I-II, ts.

Sahnûn, Ebû Saîd Abdüsselâm b. Saîd et-Tenûhî. el-Müdevvene. I-IV, Beyrut: Dâru'l-kütübi'l-ilmiyye, $1414 / 1994$.

el-Mergînânî, Ebü'l-Hasan Burhânüddîn Ali b. Ebî Bekir el-Fergânî. Muhtârâtü’n-nevâzil (nşr. Ahmet Güneş). İstanbul: İrşad Kitabevi, 1435/2014.

------. el-Hidâye şerhu Bidâyetü’l-mübtedî (nşr. Talâl Yusuf). I-IV, Beyrut: Dâru ihyâi't-türâsi'l-Arabî, ts.

Molla Hüsrev, Muhammed b. Ferâmuz b. Ali. Mirkâtü'l-vusûl ilâ ilmi'l-usûl (nşr. İlyas Kaplan), Beyrut: Dâru'l-kütübi'l-ilmiyye, 1433/2012.

Muhammed b. Abdülazîm el-Hanefî el-Mekkî. el-Kavlü's-sedîd fî ba'di mesâili'l-ictihad ve't-taklîd (trc. Hayrettin Karaman). İctihad, Taklid ve Telfik Üzerine Dört Risale, İstanbul: İz Yayıncılık, s. 73-109.

Muhammed İbrahim Ahmed Ali - Ali b. Muhammed el-Hindî el-Hanbelî. el-Mezheb inde'l-Hanefiyye veşŞâfiiyye ve'l-Mâlikiyye ve'l-Hanâbile. Kuveyt: Vizâretü'l-evkâf veş-şuûni'l-İslâmiyye, 1433/836.

el-Mutarrizî, Ebü'l-Feth Burhânüddîn Nâsır b. Abdüsseyyid b. Ali el-Hârizmî. el-Muğrib fî̀ tertîbi'l-Mu'rib. Beyrut: Dâru'l-kütübi'l-ilmiyye, 1432/2011.

Müftîzâde, Muhammed b. Hamza el-Güzelhisârî. Ezhâru't-tenzîl fî esrâri't-te’vîl. Hacı Mahmud Efendi Ktp. nr. 140.

"et-Taklîd ve talâku'l-mükreh" (nşr. Abdüsselam Arı), İslâm Hukuku Araştırmaları Dergisi, 2016, sy. 27 , s. 713-741.

------. er-Risâletü't-taklîdiye. Antalya Akseki nr. 150/18, (41a-43b)

-------. Risâle fi teaddüdi'l-müctehid. Süleymaniye nr. 1038/20, (25b-27b).

-------. Risâle fi'l-ictihâd ve't-taklid. Râşit Efendi nr. 1178/13, (31b-33b).

------. Risâle fi't-taklîdi bi'l-müctehid. Esad Efendi, nr. 3699/43, (117a-119b).

-------. Risâle fi't-taklîdi bi’l-müctehid. Çelebi Abdullah nr. 388/14, (229a-232a).

Talâk Risâlesi. Âtıf Efendi, nr. 2840/37, (73a-75b). 
Müslim b. el-Haccâc, Ebü'l-Hüseyin el-Kuşeyrî. el-Müsnedü's-sahîhu'l-muhtasar bi-nakli'l-adli ani'l-adli ilâ Rasulillahi sallallahu aleyhi ve sellem (nşr. Muhammed Fuad Abdülbâkî). I-V, Beyrut: Dâru ihyâi'ttürâsi'l-Arabî, ts.

en-Nablusî, Abdülganî b. İsmail. Hülâsatü't-tahkîk fî beyâni hükmi’t-taklîdi ve’t-telfîk. İstanbul: Işık Matbaası, ts.

Özen, Şükrü. “Osmanlı Döneminde Fetva Literatürü.” Türkiye Araştırmaları Literatür Dergisi, 2005, III, sy. 5, s. 249-378.

es-Semânî, Ebü'l-Muzaffer Mansûr b. Muhammed el-Mervezî. Kavâtiu'l-edillefî usûli’l-fikh (nşr. Muhammed Hasan İsmail). I-II, Beyrut: Dâru'l-kütübi'l-ilmiyye, 1419/1999.

es-Sübkî, Ebû Nasr Tâcüddîn Abdülvehhâb b. Ali b. Abdülkâfî. Ref'u'l-hâcib an Muhtasari İbni'l-Hâcib (nşr. Ali Muhammed Muavvaz-Âdil Ahmed Abdülmevcûd). I-IV, Beyrut: Âlemü'l-kütüb, 1419/1999.

es-Süyûtî, Ebü’l-Fazl Celâlüddîn Abdurrahman b. Ebû Bekir eş-Şâfiî. Tabakâtü̉l-müfessirîn (nşr. Ali Muhammed Ömer). Kahire: Mektebetü Vehbe, 1396/1976.

eş-Şâfiî̀, Ebû Abdullah Muhammed b. İdrîs b. Abbâs. el-Ümm. I-VIII, Beyrut: Dâru’l-márife, 1411/1990.

eş-Şeybânî, Ebû Abdullah Muhammed b. el-Hasan. Muvattaü'l-İmâm Mâlik (nşr. Takiyyüddîn en-Nedvî). I-III, Dımaşk: Dâru'l-kalem, 1432/2011.

------. Kitâbü’l-Âsâr (nşr. Hâlid el-Avvâd). I-II, Kuveyt: Dâru’n-nevâdir, 1432/2011.

Şeyhîzâde (Dâmâd Efendi), Abdurrahman b Muhammed. Mecmau'l-enhur fî şerhi Mülteka'l-ebhur. Beyrut: Dâru ihyâi't-türâsi'l-Arabî, ts.

eş-Şirbînî, Şemsüddîn Muhammed b. Ahmed el-Hatîb el-Kâhirî. Muğni'l-muhtâc ilâ marifeti elfâzi'l-Minhâc. I-VI, Beyrut: Dâru'l-kütübi'l-ilmiyye, 1415/1994.

et-Tahâvî, Ebû Cáfer Ahmed b. Muhammed el-Ezdî el-Misrî. Şerhu meâni'l-âsâr (nşr. Muhammed Zührî en-Neccâr - Muhammed Seyyid Câdülhak). I-IV, Beyrut: Dâru’l-kütübi'l-ilmiyye, 1426/2006.

et-Taşköprîzâde, Ahmed b. Mustafa Ebü'l-Hayr. eş-Şekâiku’n-nu'mâniyye fî̀ ulemâid-devleti’l-Osmâniyye. Beyrut: Dâru'l-kitâbi'l-Arabî, ts.

et-Teftâzânî Saduddîn Mes'ûd b. Ömer. Şerhü’t-Telvîh ale't-Tavdîh. I-II, yy. ts.

Yazıc1, İshak. "Semerkandî, Ebü’l-Leys”, DİA, XXXVI, 473-5.

ez-Zâhidî, Ebü’r-Recâ Necmüddîn Muhtâr b. Mahmud b. Muhammed ez-Zâhidî el-Gazmînî. el-Müctebâ (nşr. Mustafa Karaca, doktora tezi, 2010). I-III, Necmettin Erbakan Üniversitesi Sosyal Bilimler Enstitüsü.

-------. el-Kunyetü'l-münye li tetmîmi'l-ğunye. yy. ts.

ez-Zerkeşî, Ebû Abdullah Bedrüddîn Muhammed b. Bahâdır eş-Şâfiî. el-Bahru'l-muhît fî usûli'l-fikh. I-VIII, Kahire, 1414/1994.

Zeydân, Abdülkerim. el-Vecîz fì usûli’l-fikh. Beyrut: Müessesetü’r-risâle, 1427/2006

ez-Ziriklî, Ebû Gays Muhammed Hayrüddîn b. Mahmud ed-Dımaşkî. el-A'lâm, kamûsü terâcim li-eşheri'rricâl ve’n-nisâ minel-Arab ve'l-müsta'rebîn ve'l-müsteşrikîn. I-VIII, Beyrut: Dârü'l-ilmi li'l-melâyîn, $1423 / 2002$. 